\title{
High-precision U-series measurements of more than 500,000 year old fossil corals
}

\author{
Morten B. Andersen ${ }^{\mathrm{a}, \mathrm{b}, *}$, Claudine H. Stirling ${ }^{\mathrm{a}, \mathrm{c}}$, Emma-Kate Potter ${ }^{\mathrm{a}}$, \\ Alex N. Halliday ${ }^{\mathrm{a}, \mathrm{d}}$, Steven G. Blake ${ }^{\mathrm{e}}$, Malcolm T. McCulloch ${ }^{\mathrm{f}}$, \\ Bridget F. Ayling ${ }^{\mathrm{f}}$, Michael O’Leary ${ }^{\mathrm{g}}$ \\ ${ }^{a}$ ETH Zurich, Institute for Isotope Geochemistry and Mineral Resources, ETH Zentrum, Zurich, 8092 Switzerland \\ ${ }^{\mathrm{b}}$ Bristol Isotope Group, Department of Earth Sciences, University of Bristol, Parks Road, Bristol, United Kingdom \\ ${ }^{\mathrm{c}}$ Department of Chemistry, University of Otago, PO Box 56, Union Place, Dunedin, New Zealand \\ ${ }^{\mathrm{d}}$ Department of Earth Sciences, Parks Road, Oxford, OXI 3PR, United Kingdom \\ e Western Australian Marine Science Institution (WAMSI), The University of Western Australia, \\ 35 Stirling Highway, Crawley, WA 6009 Australia \\ ${ }^{\mathrm{f}}$ Research School of Earth Sciences, The Australian National University, Canberra, ACT 0200 Australia \\ ${ }^{\mathrm{g}}$ School of Earth Sciences, James Cook University, Townsville, Qld 4811 Australia
}

Received 19 October 2006; received in revised form 5 October 2007; accepted 7 October 2007

Available online 14 October 2007

Editor: M.L. Delaney

\begin{abstract}
Robust, independent age constraints on the absolute timing of climate events based on the U-series dating of fossil coral are sparse before the last glacial cycle. Using multiple-collector inductively coupled plasma mass spectrometry with multiple-Faraday protocols, we are able to date $\sim 600 \mathrm{ka}$ samples with an uncertainty of better than $\pm 15 \mathrm{ka}(2 \sigma)$, representing a three-fold improvement in precision compared with previous techniques. Using these methods, we report U-series measurements for a suite of $>500$ thousand year old (ka) corals from Henderson Island, an emergent atoll in the south-central Pacific Ocean. The fossil corals show extraordinarily little diagenetic alteration for their age and the best-preserved sample yields a U-series age of $600 \pm 15$ ka $(2 \sigma)$, which overlaps with the timing of the warm Marine Isotope Stage (MIS) 15 interglacial. The open-system model of Villemant and Feuillet [Villemant B. and Feuillet N. (2003) Dating open systems by the ${ }^{238} \mathrm{U}^{234}{ }^{23}{ }^{230}$ Th method: application to Quaternary reef terraces. Earth and Planetary Science Letters 210(1-2), 105-118.] and the linear regression (or open-system isochron) is clearly limited for such old samples. However, the open-system model developed by Thompson et al. [Thompson W.G., Spiegelman M.W., Goldstein S.L., and Speed R.C. (2003) An open-system model for U-series age determinations of fossil corals. Earth and Planetary Science Letters 210(1-2), 365-381.] appears to reliably correct for open-system effects in roughly half of the corals, giving a MIS 15 origin for these. Thus the data provide evidence that the systematic addition of ${ }^{230} \mathrm{Th}$ and ${ }^{234} \mathrm{U}$ through $\alpha-$ recoil is a dominant open-system process occurring in the Henderson Island fossil reef system. Several coral samples yield significantly older Thompson et al. open-system ages between 650 and $750 \mathrm{ka}$. The uncertainty on these ages (typically $\pm 30 \mathrm{kyrs)}$
\end{abstract}

\footnotetext{
* Corresponding author. Bristol Isotope Group, Department of Earth Sciences, University of Bristol, Parks Road, Bristol, United Kingdom. Tel.: +41 1 632 6983; fax: +41 63221179 .

E-mail address: morten.andersen@bris.ac.uk (M.B. Andersen).
} 
is too great for precise assignment but most data overlap with the MIS 17 interglacial. The reliability of these ages is currently unclear. It is shown that separate aliquots of the same coral can yield different Thompson model ages. Therefore, there appear to be additional diagenetic mechanisms that create further anomalous excursions in the U-series systematics, limiting the reliability of the Thompson et al. open-system model.

(C) 2007 Elsevier B.V. All rights reserved.

Keywords: U-Th dating; geochronology; paleoclimate; corals; MC-ICPMS; MIS 15

\section{Introduction}

Quaternary glacial-interglacial climate variability is widely believed to be driven by orbitally-induced changes in the solar radiation influx to the Earth's surface in the northern hemisphere at latitude $65^{\circ} \mathrm{N}$, as described by the Milankovitch theory of climate change (Milankovitch, 1941). This cyclic and systematic climate variability has been demonstrated in a range of important paleoclimate records, such as marine sediment $\delta^{18} \mathrm{O}$ records of ice volume and sea-level change (Imbrie et al., 1984; Bassinot et al., 1994; Lisiecki and Raymo, 2005) and ice-core $\delta \mathrm{D}$ records of air temperature variability (Petit et al., 1999; Augustin et al., 2004; Jouzel et al., 2007). Superimposed on these glacial-interglacial climate modes are abrupt climate events occurring on suborbital timescales, suggesting that other factors correlated with changes in ocean circulation patterns are important modulators of climate change on centennial-millennial timescales (e.g. Yokoyama et al., 2001; Broecker, 2003; Potter et al., 2004; Jouzel et al., 2007).

The timing of climate change can be assessed independently from direct correlation with orbital forcing theory by determining absolute radiometric ages for proxy records preserved in fossil coral reefs, aragonitic slope sediments and speleothem records (e.g. Edwards et al., 1987; Bard et al., 1990; Ludwig et al., 1992; Richards et al., 1994; Stirling et al., 1995; Esat et al., 1999; Henderson et al., 2001; Bard et al., 2002; Robinson et al., 2002). Fossil coral terraces can be linked to sea-level, ice volume and sea-surface temperature changes in the past, and an extensive record of past sea-level changes exists for the last 130 thousand years (kyr) based on the U-series dating of fossil coral reefs (e.g. Edwards et al., 1987; Hamelin et al., 1991; Stein et al., 1993; Gallup et al., 1994; Stirling et al., 1995; Bard et al., 1996; Stirling et al., 1998; McCulloch and Esat, 2000; Yokoyama et al., 2001; Cutler et al., 2004). To gain a better understanding of the mechanisms driving climate change and examine whether they are typical phenomena in the climate record, it is important to study additional glacial-interglacial transitions further back in time. However, well-dated fossil coral reefs that formed prior to the last glacial cycle are uncommon. This is because of limitations in sampling sites, the effects of diagenesis and mass spectrometric precision. Thus only well-preserved corals from a few localities recording the MIS 7 (245-193 ka) and MIS 9 (339-303 ka) interglacial periods have been comprehensively sampled and dated (Gallup et al., 1994; Stirling et al., 2001; Thompson and Goldstein, 2005).

The accuracy of the U-series chronometer is underpinned by the critical assumption of closed-system behaviour of the U-series nuclides. Therefore, remobilisation of the U-series isotopes in fossil reef systems has long been recognised as a serious limitation to U-series dating, even for samples which appear to be wellpreserved on a macroscopic level (Bender et al., 1979; Bard et al., 1991; Hamelin et al., 1991; Gallup et al., 1994; Stirling et al., 1998, 2001; Potter et al., 2004; Robinson et al., 2006). This poorly-understood opensystem alteration process is significant even for corals younger than $130 \mathrm{ka}$ (thousand of years before present), and usually increases with sample age to the extent that it often becomes necessary to reject the majority of dated samples. For fossil corals and aragonitic slope sediments, a standard way of testing the accuracy of a U-series age has been to compare the back-calculated initial ${ }^{234} \mathrm{U}^{238} \mathrm{U}$ (calculated using the measured ${ }^{234} \mathrm{U} /{ }^{238} \mathrm{U}$ and the U-series age, Table 1) with the modern ${ }^{234} U /{ }^{238} U$ seawater composition (Gallup et al., 1994; Stirling et al., 1995, 1998; Esat et al., 1999; Camoin et al., 2001; Yokoyama et al., 2001). The latter is generally assumed not to have deviated significantly away from the present-day composition at any time during the last $400 \mathrm{kyr}$ (Henderson, 2002). Thus, if a sample has an initial ${ }^{234} U{ }^{238} U$ that differs significantly from the modern seawater value then the usual approach is to assume that it has not behaved as a closed-system with respect to the U-series decay nuclides (Gallup et al., 1994; Stirling et al., 1995, 1998; Esat et al., 1999; Yokoyama et al., 2001).

To overcome the rejection of the majority of samples because of U-Th open-system behaviour, several studies have attempted to resolve the apparently systematic alteration trends in the observational data 
Table 1

U-Th isotope ratios, conventional and open-system U-series ages for Henderson Island fossil lagoon corals

\begin{tabular}{|c|c|c|c|c|c|c|c|c|c|c|c|c|c|c|c|c|}
\hline \multirow{3}{*}{ Sample ${ }^{\mathrm{b}}$} & \multirow{2}{*}{\multicolumn{2}{|c|}{$\mathrm{U}^{\mathrm{c}}$}} & \multirow{3}{*}{$\frac{{ }^{232} \mathrm{Th}}{\mathrm{ng} / \mathrm{g}}$} & \multirow{2}{*}{\multicolumn{2}{|c|}{$\delta^{234} U^{d}$}} & \multirow{2}{*}{\multicolumn{2}{|c|}{$\underline{\left[{ }^{230} \mathrm{Th} /{ }^{238} \mathrm{U}\right]_{\mathrm{act}} \mathrm{e}}$}} & \multicolumn{4}{|c|}{ Conventional } & \multirow{2}{*}{\multicolumn{3}{|c|}{$\begin{array}{l}\text { Open-system } \\
\text { models }^{\mathrm{a}} \\
{\text { Thompson et } \mathrm{al}^{\mathrm{h}}}^{\mathrm{h}}\end{array}$}} & \multirow{3}{*}{$\frac{V \& F^{i}}{k a}$} & \multirow{3}{*}{$\frac{\mathrm{LR}^{\mathrm{j}}}{\mathrm{ka}}$} \\
\hline & & & & & & & & \multicolumn{2}{|c|}{$\mathrm{Age}^{\mathrm{f}}$} & \multicolumn{2}{|c|}{$\delta^{234} \mathrm{U}_{i}^{\mathrm{g}}$} & & & & & \\
\hline & $\mu \mathrm{g} / \mathrm{g}$ & $\pm 2 \sigma$ & & $\%$ & $\pm 2 \sigma^{\mathrm{k}}$ & & $\pm 2 \sigma^{\mathrm{k}}$ & $\mathrm{ka}$ & $\pm 2 \sigma^{1}$ & & $\pm 2 \sigma^{1}$ & ka & $\pm 2 \sigma^{\mathrm{m}}$ & $\pm 2 \sigma^{\mathrm{n}}$ & & \\
\hline FL-2 & 2.21 & 0.11 & 0.01 & 33.8 & 0.3 & 1.0490 & 0.0005 & $\infty$ & & - & & 597 & (12) & 32 & & \\
\hline FL-4 & 2.12 & 0.05 & 0.01 & 29.3 & 0.3 & 1.0467 & 0.0005 & $\infty$ & & - & & 696 & (25) & 44 & & \\
\hline FL-7 & 2.14 & 0.11 & 0.01 & 31.1 & 0.3 & 1.0473 & 0.0005 & $\infty$ & & - & & 646 & (17) & 37 & & \\
\hline FL-8 & 2.12 & 0.11 & 0.01 & 35.8 & 0.3 & 1.0544 & 0.0005 & $\infty$ & & - & & 605 & (16) & 34 & & \\
\hline FL-10 & 2.25 & 0.11 & 0.01 & 32.5 & 0.3 & 1.0505 & 0.0005 & $\infty$ & & - & & 647 & (19) & 38 & & \\
\hline FL-12 & 2.12 & 0.11 & 0.02 & 31.7 & 0.3 & 1.0519 & 0.0006 & $\infty$ & & - & & 694 & (31) & 48 & & \\
\hline FL-15A & 2.14 & 0.11 & 0.02 & 28.8 & 0.3 & 1.0470 & 0.0004 & $\infty$ & & - & & 718 & (30) & 48 & & \\
\hline FL-15B & 1.97 & 0.05 & 0.02 & 30.1 & 0.3 & 1.0482 & 0.0007 & $\infty$ & & - & & 688 & (27) & 44 & & \\
\hline FL-16 & 1.95 & 0.05 & 0.01 & 33.1 & 0.3 & 1.0471 & 0.0004 & 833 & 102 & 348 & 101 & 594 & (11) & 31 & & \\
\hline$F L-22$ & 1.78 & 0.04 & 0.01 & 39.2 & 0.3 & 1.0468 & 0.0004 & 528 & 7 & 174 & 4 & 498 & (5) & 23 & & \\
\hline NFL-25A & 2.14 & 0.11 & 0.02 & 29.1 & 0.3 & 1.0404 & 0.0004 & 721 & 39 & 224 & 24 & 615 & (10) & 31 & & \\
\hline NFL-25B & 1.99 & 0.05 & 0.02 & 29.0 & 0.3 & 1.0423 & 0.0009 & $\infty$ & & - & & 642 & (17) & 36 & & \\
\hline NFL-27A & 2.41 & 0.12 & 0.04 & 30.2 & 0.3 & 1.0427 & 0.0007 & 791 & 98 & 283 & 78 & 614 & (12) & 32 & & \\
\hline NFL-27B & 2.19 & 0.05 & 0.01 & 30.8 & 0.3 & 1.0415 & 0.0004 & 657 & 23 & 198 & 13 & 589 & (8) & 29 & & \\
\hline$N F L-28$ & 2.01 & 0.05 & 0.01 & 37.1 & 0.3 & 1.0502 & 0.0005 & 652 & 23 & 234 & 16 & 546 & (8) & 27 & & \\
\hline NFL-31A & 2.14 & 0.11 & 0.01 & 25.8 & 0.3 & 1.0367 & 0.0005 & 855 & 140 & 289 & 114 & 660 & (13) & 35 & & \\
\hline NFL-31B & 1.96 & 0.05 & 0.01 & 26.1 & 0.3 & 1.0378 & 0.0004 & $\infty$ & & - & & 666 & (14) & 36 & & \\
\hline NFL-50A & 2.17 & 0.11 & 0.01 & 29.4 & 0.3 & 1.0367 & 0.0005 & 585 & 13 & 153 & 6 & 576 & (7) & 28 & & \\
\hline NFL-50B & 2.16 & 0.11 & 0.02 & 27.9 & 0.3 & 1.0353 & 0.0005 & 600 & 15 & 152 & 7 & 593 & (8) & 29 & & \\
\hline \multirow[t]{2}{*}{ NFL-50C } & 2.56 & 0.13 & 0.03 & 35.3 & 0.3 & 1.0497 & 0.0005 & 758 & 58 & 301 & 50 & 572 & (10) & 29 & & \\
\hline & & & & & & & & & & & & & & & $\begin{array}{l}889 \\
(+188 /-139)\end{array}$ & $\begin{array}{l}613 \\
(+\infty /-58)\end{array}$ \\
\hline \multicolumn{4}{|c|}{$\begin{array}{l}\text { Pacific seawater Henderson } \\
\text { Island }\end{array}$} & 147.1 & 0.3 & & & & & & & & & & & \\
\hline \multicolumn{4}{|c|}{ Living Oeno porites } & 146.8 & 0.3 & & & & & & & & & & & \\
\hline
\end{tabular}

${ }^{\text {a }}$ All open-system U-series model ages are calculated using the present-day seawater $\delta^{234} U=147 \%$ and half-lives adopted from Cheng et al. (2000).

b A, B and C indicate replicate analyses on the same sample. All samples are from the Faviidae and Montastria family and are for wall fractions only, except for bulk sample NFL-50C. All corals are derived of $>99 \%$ aragonite based on XRD measurements (detection limit $\sim 1 \%$ ), except for FL-22 and NFL-28 which contain 1-2\% calcite (in italics). All samples were collected at a similar elevation of $27 \pm 3 \mathrm{~m}$ above mean sea-level.

${ }^{c}$ Uranium concentrations are obtained from measured ${ }^{233} \mathrm{U}{ }^{238} \mathrm{U}$. Errors are estimated as either $0.5 \%$ or $0.25 \%$ dependent on the weighing method; weighing errors contribute as the major source.

$\left.{ }^{\mathrm{d}} \delta^{234} \mathrm{U}=\left\{\left[{ }^{234} \mathrm{U} /{ }^{238} \mathrm{U}\right) /\left({ }^{234} \mathrm{U} /{ }^{238} \mathrm{U}\right)_{\mathrm{eq}}\right]-1\right\} \times 10^{3} .\left({ }^{234} \mathrm{U} /{ }^{238} \mathrm{U}\right)_{\mathrm{eq}}$ is the atomic ratio at secular equilibrium and is equal to $\lambda_{238} / \lambda_{234}=5.4891 \times 10^{-5}$, where $\lambda_{238}$ and $\lambda_{234}$ are the decay constants for ${ }^{238} U$ and ${ }^{234} \mathrm{U}$, respectively, adopting the half-lives of Cheng et al. (2000).

e $\left[{ }^{230} \mathrm{Th} /{ }^{238} \mathrm{U}\right]_{\mathrm{act}}=\left({ }^{230} \mathrm{Th} /{ }^{238} \mathrm{U}\right) /\left(\lambda_{238} / \lambda_{230}\right)$.

${ }^{\mathrm{f}} \mathrm{U}$-series ages are calculated iteratively using: $1-\left[{ }^{230} \mathrm{Th} /{ }^{238} \mathrm{U}\right]_{\mathrm{act}}=\exp ^{-\lambda}{ }^{230 \mathrm{~T}}-\left(\delta^{234} \mathrm{U} / 1000\right)\left(\lambda_{230} /\left(\lambda_{230}-\lambda_{234}\right)\right)\left(1-\exp ^{(2234-\lambda 230) T}\right) \mathrm{where} T$ is the age in years and $\lambda_{230}$ is the decay constant for ${ }^{230} \mathrm{Th} . \lambda_{238}=1.551 \times 10^{-10} \mathrm{y}^{-1} ; \lambda_{234}=2.826 \times 10^{-6} \mathrm{y}^{-1} ; \lambda_{230}=9.158 \times 10^{-6} \mathrm{y}^{-1}$.

g The initial value is given by $\delta^{234} \mathrm{U}_{i}=\delta^{234} \mathrm{U}_{\exp }{ }^{\lambda 234 \mathrm{~T}}$, where $T$ is the age in years.

${ }^{\mathrm{h}}$ Results for the Thompson et al. open-system model, the details of which can be found in Thompson et al. (2003).

${ }^{i}$ Results for the V\&F open-system model (Villemant and Feuillet, 2003). No age errors are incorporated for single data points, since all samples are assumed to be coeval. Error estimates are based on the total age variability shown by all samples (see (Villemant and Feuillet, 2003)).

${ }^{\mathrm{j}}$ Results for the LR - Linear regression open-system model (see Potter et al. 2004, Scholz \& Mangini 2006). Errors for the linear regression approach are based on the $95 \%$ confidence level of the regression line, and where these intercept with the seawater evolution curve.

${ }_{\mathrm{k}}$ All activity ratios are calculated by normalisation to HU-1 assuming secular equilibrium. Reported errors include (1) the long-term reproducibility $(2 \sigma)$ of the standards or, for some samples, the internal measurement uncertainty of the sample $\left(2 \sigma_{\mathrm{M}}\right)$, whichever is the larger, and (2) errors $\left(2 \sigma_{\mathrm{M}}\right)$ in the isotope ratios associated with the HU-1 measurements.

${ }^{1}$ The uncertainty in the U-series age includes the analytical contribution from the parameters $\delta^{234} \mathrm{U}$ and $\left[{ }^{230} \mathrm{Th} /{ }^{238} \mathrm{U}\right]$ act. Decay constant uncertainties are not incorporated because their contribution to the total age uncertainty at $\sim 600 \mathrm{ka}$ is negligible. Age uncertainties are determined using a first order estimation. For samples with age uncertainties of $>20 \mathrm{ky}$ a "Monte Carlo" method would give a more appropriate estimate of the age uncertainty, however in the present study, all samples with age uncertainties of this large magnitude are deemed unreliable because of the large $\delta^{234} \mathrm{U}_{i}$.

${ }^{m}$ Errors include estimates for the correction parameters and analytical contributions from the $\delta^{234} \mathrm{U}$ and $\left[{ }^{230} \mathrm{Th} /{ }^{238} \mathrm{U}\right]_{\text {act }}$ (see (Thompson et al., 2003)) but do not include the contribution arising from the uncertainty in the $\delta^{234} \mathrm{U}$ for seawater (147\%o) through the Quaternary.

${ }^{\mathrm{n}}$ Errors are the same as Footnote $\mathrm{m}$ and also include the contribution arising from the uncertainty in the $\delta^{234} \mathrm{U}$ for seawater (147 $\pm 20 \%$ ) prior to MIS 9 $(>340 \mathrm{ka})$. 
by devising "open-system U-series models". These models may offer the potential to convert inaccurate conventional U-series age determinations into reliable open-system U-series model ages (Henderson et al., 2001; Thompson et al., 2003; Villemant and Feuillet, 2003; Scholz et al., 2004; Thompson and Goldstein, 2005; Scholz and Mangini, 2006; Thompson and Goldstein, 2006; Scholz and Mangini, 2007). However, given the limited understanding of the range of physical processes controlling U-Th open-system behaviour and how these effects vary with time and geographic location, it is imperative that these models are extensively tested against a wide range of fossil coral U-series age data to assess their robustness.

Another important factor that limits the application of U-series dating is the severe loss in resolution of the chronometer for samples approaching secular equilibrium (>400 ka). Near this upper limit of the U-series chronometer, dating becomes extremely challenging because the age-related differences in isotopic composition progressively decrease as the sample age increases. U-series dating has developed considerably during the last 20 years due to significant advances in thermal ionization mass spectrometry (TIMS), and more recently, multiple-collector inductively coupled plasma mass spectrometry (MC-ICPMS). Recent mass spectrometric techniques now routinely achieve measurement precisions at the per mil level for the determination of the ${ }^{234} \mathrm{U}$ and ${ }^{230} \mathrm{Th}$ relative abundances (Esat, 1995; Luo et al., 1997; Stirling et al., 1998; Cheng et al., 2000; Henderson et al., 2001; Stirling et al., 2001; Robinson et al., 2002; Goldstein and Stirling, 2003; Fietzke et al., 2005; Hoffmann et al., 2005). However, the dating of extremely old samples $(>500 \mathrm{ka})$ requires even further improvements in analytical precision.

In this study, well-preserved $>500$ ka fossil corals from Henderson Island (Fig. 1), are dated with exceptionally high-precision by employing fundamentally new techniques in U-series mass spectrometry. These data offer a unique opportunity to test the accuracy of both conventional and open-system age estimates for corals at the upper limit of the U-series chronometer.

\section{Methods}

Using MC-ICPMS and a multiple-Faraday detector array in place of the usual electron multiplier configuration adopted in standard U-series mass spectrometry, it allows measurements of $\left[{ }^{230} \mathrm{Th} /{ }^{238} \mathrm{U}\right]_{\text {act }}$ and $\delta^{234} \mathrm{U}$ (representative of the activity ratios for ${ }^{230} \mathrm{Th} /{ }^{238} \mathrm{U}$ and ${ }^{234} \mathrm{U} /{ }^{238} \mathrm{U}$, respectively, with the latter reformulated into $\delta$-notation as $\left.\delta^{234} \mathrm{U}=\left(\left({ }^{234} \mathrm{U} /{ }^{238} \mathrm{U}_{\text {sample }}\right) /\left({ }^{234} \mathrm{U} /{ }^{238} \mathrm{U}_{\text {sec.eq. }}\right)-1\right) \times 10^{3}\right)$ with precisions better than $\pm 0.4 \%$ o $(2 \sigma)$ and $\pm 0.3 \%$ o $(2 \sigma)$, respectively (see Supplementary data and Fig. 2). Using this improved measurement precision we can now date a $\sim 600 \mathrm{ka}$ sample with an associated uncertainty of $\pm 15 \mathrm{ka}(2 \sigma)$ (Andersen et al., 2004; Potter et al., 2005). This represents a significant improvement over previously published methodologies, for which even the most precise techniques yield age uncertainties of $\pm 40 \mathrm{ka}$ for samples in this age range (Stirling et al., 2001).

\section{Locality description and samples}

Henderson Island is an emergent atoll and part of the Pitcairn Island Group, located at $24.2^{\circ} \mathrm{S}$ and $128.2^{\circ} \mathrm{W}$ in the South Pacific Ocean (Fig. 1A). Quaternary volcanic activity on nearby Pitcairn Island (Duncan et al., 1974), located $\sim 200 \mathrm{~km}$ south-southwest of Henderson Island, has evidently resulted in the slow and systematic emergence of Henderson Island by volcanic loading and consequent lithospheric flexure-related bulge processes (McNutt, 1978) which have elevated the plateau of the interior fossil lagoon to $\sim 30 \mathrm{~m}$ above present sealevel (Fig. 1).

Henderson Island is geographically remote which, together with its extreme position at the south-east margin of the Indo-Pacific subtropical belt, has made its coral reefs very sensitive to climatic and ecological changes (Benton and Spencer, 1995). This implies that several environmental criteria must be fulfilled in order for prolific coral growth to occur on the island. Specifically, even if marine surface-water temperatures are sufficiently high to trigger widespread coral growth, other factors, and especially the ability to transport coral larvae to the Pitcairn Island group via island jumping from the Pacific islands to the north-west (Irving, 1995; Paulay, 1989), are required to promote widespread coral reef development. Also, following the uplift of the island, when the interior fossil lagoon was elevated above sea-level, coral growth became limited to the island's margins, representing a high wave energy environment in which present-day coral development is scarce (Benton and Spencer, 1995; Blake, 1995; Irving, 1995; Pandolfi, 1995; Ayling et al., 2006). For example, older reef-growth episodes, including those correlated with MIS 9 and older climate events, have not been overgrown subsequently by younger MIS 5.5 or Holocene reef complexes (Stirling et al., 2001).

Despite their extreme old age, Henderson Island's fossil corals are exceptionally well-preserved. The island is situated near the centre of the South Pacific 

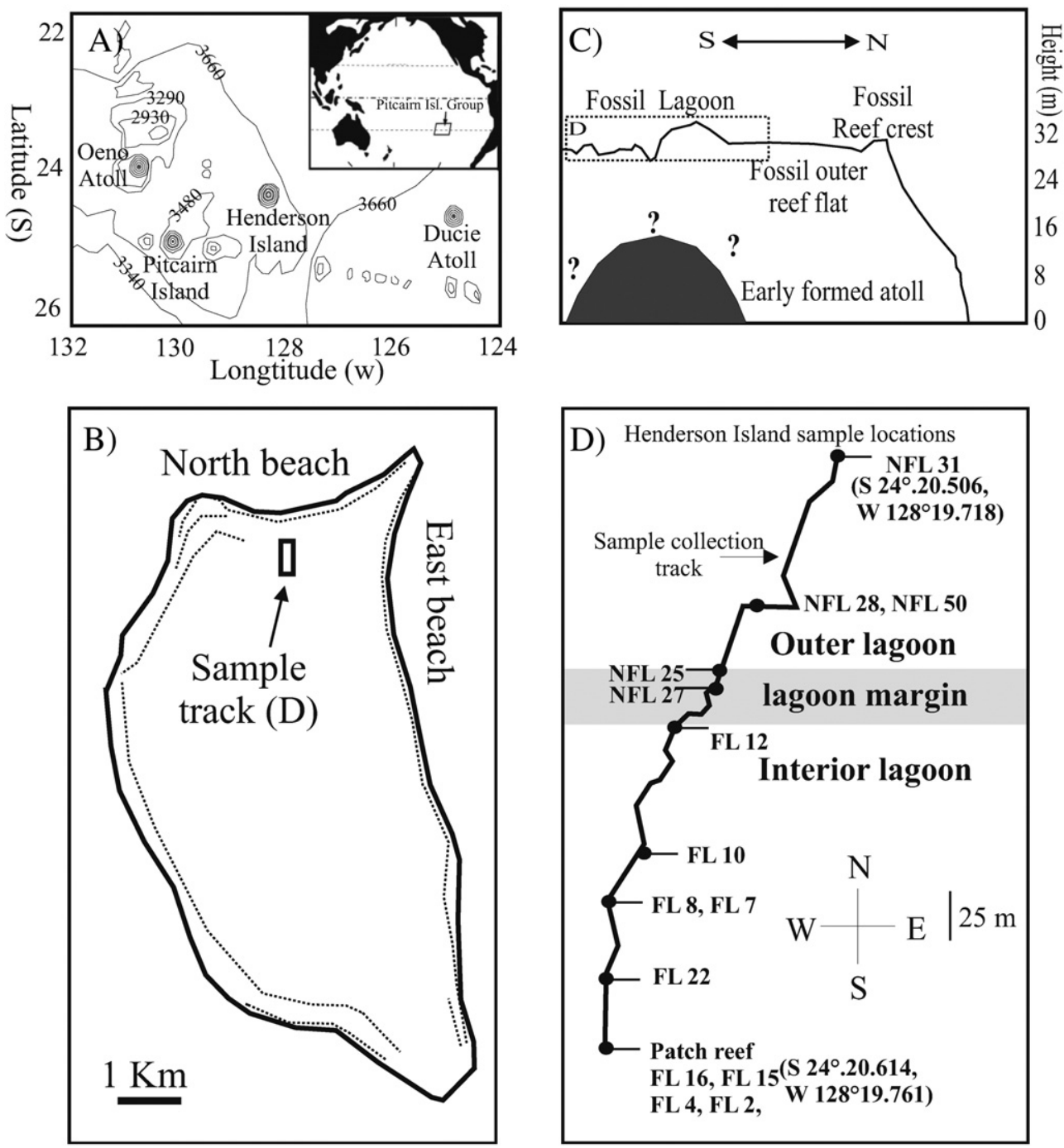

Fig. 1. A) Map showing the locality of Henderson Island in the South Pacific Ocean. B) Arial overview of Henderson Island; the stippled lines indicate the location of steep cliffs (>10 m elevation). The box indicates where samples were collected. C) Schematic cross-section of Henderson Island, indicating the area of sample collection as the stippled box marked "D". D) Location of the sample collection transect extending from the North Beach south-eastwards through the Henderson Island fossil lagoon. Samples labelled NFL were sampled north and outside of the fossil lagoon, whereas samples labelled FL were sampled inside the fossil lagoon. Samples were collected during an expedition to Henderson Island in 2003. Figures A, B and C are modified from Stirling et al. (2001) and Blake (1995).

gyre; the average rainfall for nearby Pitcairn Island is $\sim 1700 \mathrm{~mm}$ per year and a comparable value is inferred for Henderson Island (Spencer, 1995). This semi-arid climate promotes the preservation of fossil corals. The geographic isolation of the island also minimizes any detrital contamination from continental sources (Stirling et al., 2001; Ayling et al., 2006). In addition, the samples for the present study were collected during a field expedition to Henderson Island in 2003 from the elevated upper plateau of the fossil atoll structure of the island (Blake, 1995; Pandolfi, 1995). This has further removed these corals from interaction with potential seawater and groundwater sources throughout much of the last $\sim 600 \mathrm{kyr}$.

The samples were collected along a NE-SW transect extending from the North Beach seaward margin towards the interior of the island (Fig. 1D). This transect follows the slightly seaward-dipping fossil outer reef flat, dominated by carbonate pinnacle features with interstitial carbonate rubble of branching fossil corals and carbonate debris. The fossil lagoon reef crest, located $\sim 250$ meters (m) inland, is characterised by a $15 \mathrm{~m}$ wide pinnacle crest 

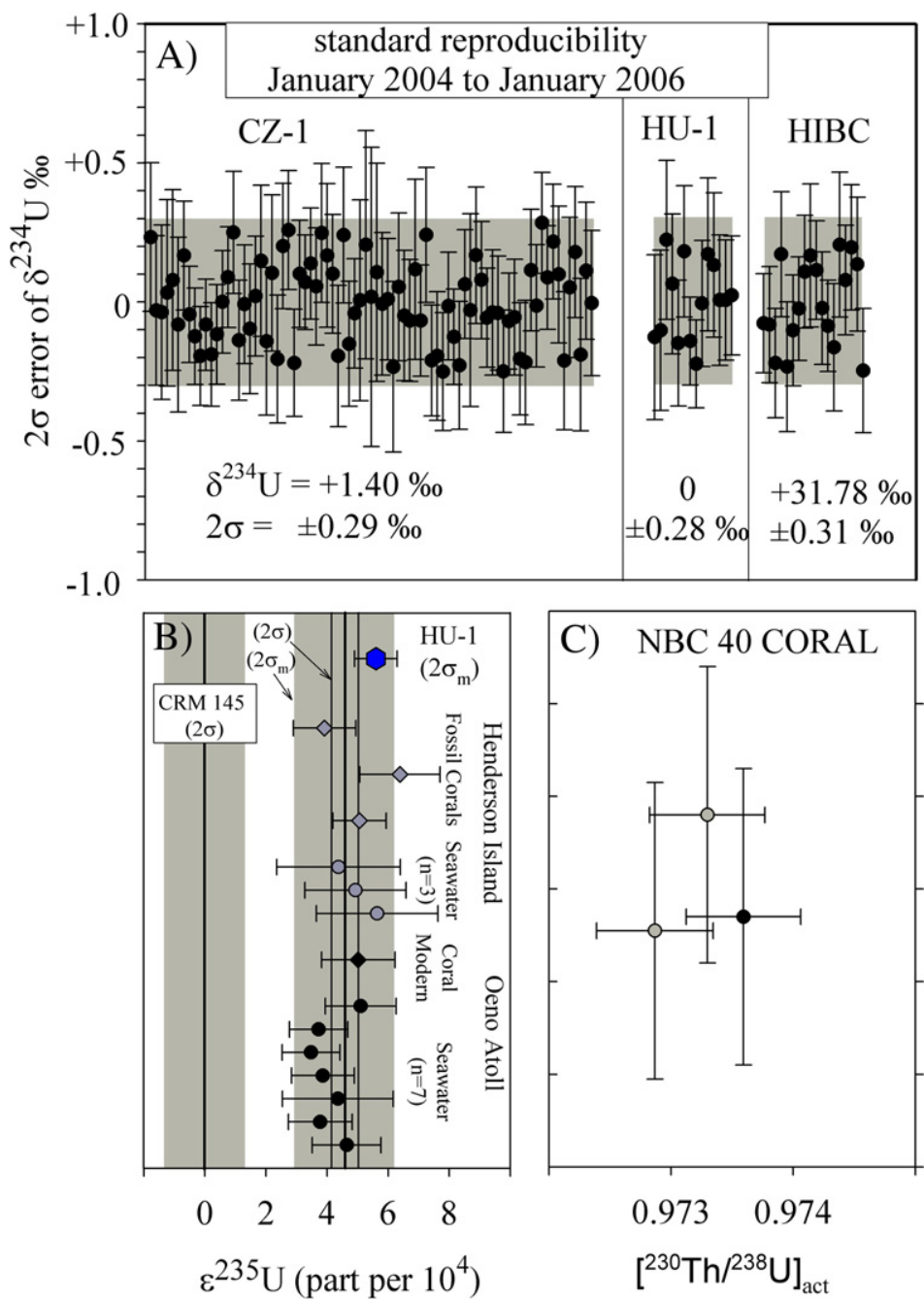

74.8

74.6

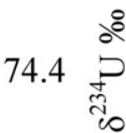

74.2

74.0

73.8

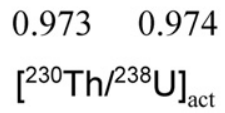

Fig. 2. A) Repeat $\delta^{234} \mathrm{U}$ measurements for purified uraninites (CZ-1 and HU-1) and coral (HIBC) standards showing a long-term $2 \sigma$ external reproducibility of $\pm 0.3 \%$. B) ${ }^{235} \mathrm{U} /{ }^{238} \mathrm{U}$ composition for HU-1 and a suite of fossil corals and seawater samples collected from the Pacific region, expressed as the fractional deviation away from the CRM-145 standard in epsilon units as $\varepsilon^{235} U$ ( 1 epsilon=1 part in $\left.10^{4}\right)$. The seawater and coral samples have ${ }^{235} U^{238} U$ that are identical within error $(2 \sigma)$ and plot within 1 epsilon of the value obtained for HU-1, but are distinct from the $\varepsilon^{235} U$ composition of CRM-145 (defined as 0) (Stirling et al., in press). When this variability in ${ }^{235} \mathrm{U}^{238} \mathrm{U}$ is incorporated into the $\delta^{234} \mathrm{U}$ determination, a $\delta^{234} \mathrm{U}$ value of $-36.90 \pm 0.08 \%$ o $\left(2 \sigma_{\mathrm{M}}, n=14\right)$ is derived for CRM-145, assuming HU-1 is in secular equilibrium with respect to ${ }^{234} \mathrm{U}$ and ${ }^{238} \mathrm{U}$. C) Independently spiked and chemically processed coral fragments of Henderson Island coral NBC 40 which show good agreement for $\delta^{234} \mathrm{U}$ and $\left[{ }^{230} \mathrm{Th} /{ }^{238} \mathrm{U}\right]_{\text {act }}$ Using multiple-Faraday protocols.

that is elevated by $1.0-1.5 \mathrm{~m}$ with respect to the surrounding fossil outer reef flat and by $\sim 2 \mathrm{~m}$ with respect to the adjacent interior fossil lagoon. The interior fossil lagoon contains identifiable fossil patch reef structures, preserved as platforms outcropping $\sim 0.5 \mathrm{~m}$ higher than the surrounding fossil lagoon platform, that are $\sim 20 \mathrm{~m}$ in diameter. The fossil coral assemblages in the patch reef structures are diverse and include branching (Pocilliopora, Acropora, Pavona, Stylophora, Astropora) and head (Faviidae, Porites) coral species preserved both as rubble and in growth position.
Fourteen of the 50 collected fossil corals, located in growth position and showing the least diagenetic alteration were selected for U-series isotopic analysis based on the following physical selection criteria: no detectable calcite recrystallization $(<1 \%)$, minimal secondary aragonite formation and no brownish discolouration (owing to the presence of large amount of organic material). The selected fossil corals were separated into two geomorphologicallydistinct units: (1) samples collected inside the interior fossil lagoon (FL) and (2) samples collected on the outer rim/ northern side of the lagoon reef crest (NFL) (Fig. 1D). The 
close proximity of the coral outcrops and the species similarity between assemblages suggests that they could have formed during the same growth episode, although the possibility of subsequent recolonisation by younger corals during later sea-level high-stands cannot be ruled out. All of the dated corals are of the thick-walled Faviidae family.

Previous U-series age constraints for Henderson Island have revealed that major coral terraces formed as fringing reefs during MIS 9 (339-303 ka), primarily on the margins of the emerged island, and as an older interior fossil lagoon that formed during earlier interglacial events (Stirling et al., 2001). Limited U-series age constraints for the fossil lagoon suggested that reef growth occurred at $\sim 630 \mathrm{ka}$, and were tentatively correlated with the MIS 15 interglacial (Stirling et al., 2001). However, potential $\mathrm{U}-\mathrm{Th}$ open-system behaviour in these old samples,
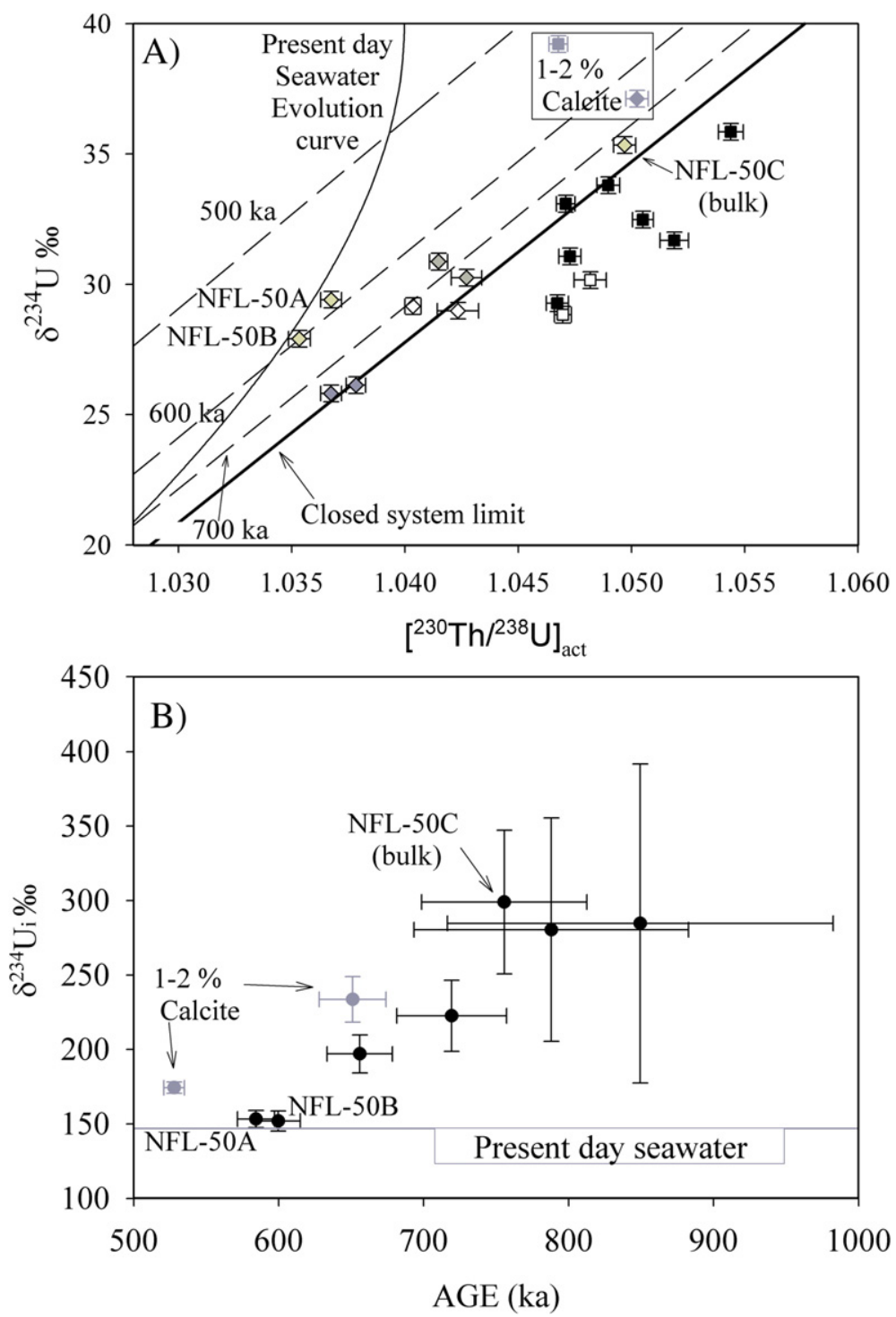

Fig. 3. A) $\left[{ }^{230} \mathrm{Th} /{ }^{238} \mathrm{U}\right]$ act versus $\delta^{234} \mathrm{U}$ for the fossil corals sampled from the Henderson Island fossil lagoon. The hypothetical seawater evolution curve, constrained by the present $\delta^{234} \mathrm{U}$ of $147 \%$, is assumed to be invariant through time and is shown for reference. Diamond symbols denote NFL samples and square symbols represent FL samples. Data points of the same colour indicate replicate measurements of the same coral sample. Full grey symbols indicate samples containing 1-2\% calcite. The fossil lagoon corals show an alteration trend that is characterized by a coupled, linear shift in both $\delta^{234} \mathrm{U}$ and $\left[{ }^{230} \mathrm{Th} /{ }^{238} \mathrm{U}\right]_{\text {act }}$ towards more elevated values. Samples NFL-50A and B have the lowest coupled $\delta^{234} \mathrm{U}$ and $\left[{ }^{230} \mathrm{Th} /{ }^{238} \mathrm{U}\right]$ act ${ }^{\mathrm{values}}$. B) Conventional U-series ages versus $\delta^{234} U_{i}$ for the above-mentioned samples. Seven out of 20 samples have U-Th isotopic compositions yielding conventional ages that can be defined by the U-series chronometer. NFL-50A and NFL-50B have $\delta^{234} \mathrm{U}_{i}$ that overlap the present-day marine $\delta^{234} \mathrm{U}$. 
coupled with limitations in the precision associated with conventional electron multiplier measurements, meant that the U-series age estimates could not resolve interglacial from glacial aged periods (Stirling et al., 2001).

\section{Results}

Here we present twenty new high-precision U-series measurements for fourteen fossil corals (Table 1 and Fig. 3). Despite the remarkably good preservation of these corals, alteration in many $>500$ ka samples are inevitable and the samples show a U-Th open-system trend represented by a coupled broadly linear shift towards elevated values in $\left[{ }^{230} \mathrm{Th} /{ }^{238} \mathrm{U}\right]_{\text {act }}-\delta^{234} \mathrm{U}$ space (Fig. 3). Fossil corals FL-22 and NFL-28 have the highest measured $\delta^{234} U(37.1-39.2 \%)$ and are the only samples containing detectable calcite $(\sim 1-2 \%)$. Also, both samples have $\left[{ }^{230} \mathrm{Th} /{ }^{238} \mathrm{U}\right]_{\text {act }}$ and $\delta^{234} \mathrm{U}$ values that depart from the general linear trend displayed by the full dataset (Fig. 3). These samples yield both conventional and Useries open-system ages that are markedly different from the rest of the dataset (Table 1); their results are thus deemed unreliable and will be omitted from further calculations and discussion. The clear separation with respect to U-series isotopic composition of samples containing trace levels of calcite from those containing no calcite clearly demonstrates that coral-screening criteria based on no detectable calcite must be applied to samples with such elevated ages. For five corals, two or three replicate measurements of the same sample were acquired (based on the independent chemical processing of different wall fragments that have been physically separated from the septa fraction). Of these, one displays replicate $\left[{ }^{230} \mathrm{Th} /{ }^{238} \mathrm{U}\right]$ act and $\delta^{234} \mathrm{U}$ that are identical within the limits of the reported measurement uncertainties, while the four other replicated samples show variable $\left[{ }^{230} \mathrm{Th} /{ }^{238} \mathrm{U}\right]_{\text {act }}$ and $\delta^{234} \mathrm{U}$ compositions due to spatially variable $\mathrm{U}-\mathrm{Th}$ opensystem behaviour in the coral skeleton. Heterogeneity in the $\mathrm{U}-\mathrm{Th}$ isotopic composition is particularly significant in the bulk sample (representing the unseparated wall and septa fractions) of NFL-50C, which is characterized by respective $\left[{ }^{230} \mathrm{Th} /{ }^{238} \mathrm{U}\right]_{\text {act }}$ and $\delta^{234} \mathrm{U}$ values that are $\sim 13 \%$ and $\sim 5 \%$ higher than independent measurements for wall fractions of the same coral (Fig. 3).

\section{Discussion}

\subsection{Uranium-series open-system behaviour}

The systematic U-Th open-system behaviour that appears in this Henderson Island dataset is similar to observations for many independent fossil coral locali- ties, irrespective of local weathering patterns and the age of reef formation (Gallup et al., 1994; Stirling et al., 1998; Stirling et al., 2001; Potter et al., 2004), which has led to the development of open-system U-series models (Thompson et al., 2003; Villemant and Feuillet, 2003; Scholz et al., 2004; Scholz and Mangini, 2006). Our dataset provides a unique opportunity to critically evaluate the reliability of these open-system models and the veracity of conventional U-series dating for very old samples for two key reasons. First, the old age of the Henderson Island samples means that any departures in the open-system U-series model age away from the true age will be amplified if additional sources of error are present but have not been taken into consideration by the model assumptions. Second, the ability to detect possible biases in the open-system U-series model ages towards anomalous values will only be resolvable in very old samples if they are measured with sufficiently high-precision, as has been demonstrated by the results presented in this study.

\subsection{Age calculations}

In the following sections, conventional U-series age determinations and the results obtained using several open-system models are compared and discussed in relation to the Henderson Island fossil lagoon dataset. Open-system models by Thompson et al. (2003), Villemant and Feuillet (2003), and the linear regression model (Potter et al., 2004; Scholz and Mangini, 2006), referred to herein as "Thompson et al", "V\&F" and "LR", respectively, will be evaluated. The details of each model are briefly summarized below.

- The model of Thompson et al. is based on $\alpha$-recoil processes, whereby thorium daughter isotopes $\left({ }^{234} \mathrm{Th}\right.$ and ${ }^{230} \mathrm{Th}$ ) are susceptible to redistribution. Calculations are modified from the open-system model of Henderson and Slowey (2000) developed for aragonitic slope sediments. Differential equations, taking into account (1) radioactive decay of the U-series nuclides, (2) ${ }^{234} \mathrm{Th}$ and ${ }^{230} \mathrm{Th}$ addition (or loss) by $\alpha$ recoil redistribution and (3) the seawater evolution curve with respect to ${ }^{234} \mathrm{U}$ and ${ }^{230} \mathrm{Th}$, allow the derivation of an age for individual samples as a theoretical forward model. The model assumes that $\alpha$ recoil mobilisation is the only $\mathrm{U}-\mathrm{Th}$ alteration process operating within the reef unit, and does not include a method to correct for the presence of initial ${ }^{230} \mathrm{Th}$.

- The V\&F model is also based on $\alpha$-recoil principles presented in Henderson and Slowey (2000). It differs from the Thompson et al. (2003) model in that it 
corrects for the presence of initial thorium and calculates one "average" open-system U-series model age for the entire reef unit, based on an integration of data for all samples, making the critical assumption that all corals developed concurrently.

- The LR or "open-system isochron" approach calculates a regression line through the coral data in the $\left[{ }^{230} \mathrm{Th} /{ }^{238} \mathrm{U}\right]_{\text {act }}-\delta^{234} \mathrm{U}$ space, which is independent of the systematics of $\alpha$-recoil addition, but assumes a linear relationship between ${ }^{230} \mathrm{Th}$ and ${ }^{234} \mathrm{U}$. The point at which this regression line intercepts the seawater evolution curve gives an average opensystem U-series model age for the reef unit. In a similar manner to the V\&F model, this model also makes the inherent interpretation that all corals are coeval.

\subsection{The marine $\delta^{234} U$}

Importantly, all of the above-mentioned open-system models make the inherent assumption that the marine $\delta^{234} \mathrm{U}$ value has not diverged significantly away from the modern seawater value at any time during the late Quaternary. This critical assumption becomes increasingly important for older samples for two reasons. First, a knowledge of the marine $\delta^{234} \mathrm{U}$ is limited further back in time, particularly for the time interval prior to $400 \mathrm{ka}$ (Henderson, 2002). Second, if the marine $\delta^{234} U$ deviated from the present-day value in the past, then the opensystem U-series model ages will be biased towards anomalous estimates. The latter is also an important issue for conventional closed-system ages if these are screened with a fixed, but incorrect, marine $\delta^{234} \mathrm{U}$ value. We determined a $\delta^{234} \mathrm{U}$ of $147.1 \pm 0.3 \%$ for surface seawater sampled offshore from Henderson Island (Table 1). This value is in perfect agreement with other high-precision data that we have acquired in independent studies of north Pacific seawater $\left(\delta^{234} U=146.9 \pm 0.3 \%\right.$ o, $2 \sigma$, (Andersen, 2006)) and deep ocean seawater from the Arctic $\left(\delta^{234} \mathrm{U}=147.3 \pm 0.3 \%\right.$ o, $2 \sigma$ (Andersen et al., 2007)), as well as with other less precise $\delta^{234} U$ seawater constraints (Chen et al., 1986; Delanghe et al., 2002; Robinson et al., 2004a). These seawater $\delta^{234} \mathrm{U}$ constraints are furthermore within error of measurements for a living Porites coral sampled from nearby Oeno atoll $\left(\delta^{234} \mathrm{U}\right.$ of $146.8 \pm 0.3 \%$, $2 \sigma$ ), confirming that living corals uptake $U$ from seawater without creating a notable fractionation of $\delta^{234} \mathrm{U}$.

A marine $\delta^{234} \mathrm{U}$ of $147 \%$, identical to the modern ocean composition, has been adopted for all the three open-system model calculations, in order to directly compare the performance of each model. The validity of adopting the modern marine $\delta^{234} \mathrm{U}$ composition as a boundary condition for the open-system model calculations is discussed below, as it is important to note that there is an increasing body of data implying that the $\delta^{234} \mathrm{U}$ of seawater may have been lower than the present $147 \%$ during the last glacial cycle, based on widespread conventional U-series dating of fossil reefs (Cutler et al., 2004; Potter et al., 2004; Esat and Yokoyama, 2006). This contrasts with past marine $\delta^{234} \mathrm{U}$ estimates from fossil corals for warm interglacial periods, including the Holocene, MIS 5.5, MIS 7.1 and MIS 9, all of which suggest that the marine $\delta^{234} \mathrm{U}$ returned to within a few per mil of the present-day value of $147 \%$ despite possible glacial-interglacial variation (Edwards et al., 1993; Gallup et al., 1994; Stirling et al., 1995, 1998; Stirling et al., 2001; Cutler et al., 2004).

The marine $\delta^{234} \mathrm{U}$ and $\mathrm{U}$ concentration budget are largely dominated by riverine $U$ inputs, which in turn, are dominated by the type and intensity of weathering (Chen et al., 1986; Chabaux et al., 2003; Robinson et al., 2004b). Thus, large fluctuations in the riverine flux of $\delta^{234} \mathrm{U}$ and/ or U concentration (e.g. see (Henderson, 2002)) could potentially create significant variations in the marine $\delta^{234} \mathrm{U}$ over time. With respect to Henderson Island, measured Faviidae fossil corals from the fossil lagoon have U concentrations ranging from 1.95 to $2.41 \mathrm{ppm}$ (wall fragments; Table 1) which is similar to Faviidae fossil corals sampled from MIS 9 reefs (wall fragments; 1.99-2.39 ppm U, (Andersen, 2006)) suggesting that the marine $\mathrm{U}$ concentration was similar at the timing of the fossil lagoon coral formation and during MIS 9 $(\sim 320 \mathrm{ka})$. Several independent studies using different modelling approaches with a fixed marine $U$ concentration have estimated that changes of up to $20 \%$ could be possible on time scales of a few hundred thousand years (Hamelin et al., 1991; Richter and Turekian, 1993; Edwards et al., 2003; Henderson, 2002). Assuming the marine $\delta^{234} \mathrm{U}$ was similar to the present-day value $(147 \%$ ) at $\sim 320 \mathrm{ka}$ (Stirling et al., 2001), we suggest that a $\delta^{234} \mathrm{U}$ of $147 \pm 20 \%$ provides a good first order approximation of the marine $\delta^{234} \mathrm{U}$ during interglacialinterstadial periods occurring prior to MIS 9. For samples older than MIS 9, this $\pm 20 \%$ error assigned to the marine $\delta^{234} \mathrm{U}$ should be propagated through all open-system age calculations to circumvent the dependence of the model calculations on the assumption of a constant and uniform marine $\delta^{234} \mathrm{U}$ throughout the Quaternary.

\subsection{Conventional U-series ages}

In addition to the macroscopic screening criteria mentioned in Section 3, measured ${ }^{232} \mathrm{Th}$ and $\mathrm{U}$ concentration may also be used to screen out unreliable corals. High 
${ }^{232} \mathrm{Th}$ is an indicator for alteration and/or contamination of the coral and anomalous $U$ concentrations can indicate uranium loss/gain. The threshold for what is deemed reliable can be difficult to set unequivocally however all the samples in this study had very low amount of ${ }^{232} \mathrm{Th}$ $(<0.04 \mathrm{ppb})$ and a limited range of $U$ concentrations (1.95-2.56 ppm) so no samples are excluded using these criterions. Further test for the $\mathrm{U}-\mathrm{Th}$ alteration and the reliability of conventional U-series ages for samples fulfilling the above-mentioned criterions should be done in the $\left[{ }^{230} \mathrm{Th} /{ }^{238} \mathrm{U}\right]_{\mathrm{act}}-\delta^{234} \mathrm{U}$ space, looking for systematic open-system behaviour, characterized by progressively higher $\left[{ }^{230} \mathrm{Th} /{ }^{238} \mathrm{U}\right]_{\text {act }}$ and $\delta^{234} \mathrm{U}$ due to $\alpha$-recoil addition processes (Stirling et al., 1998; Esat and Yokoyama, 2006). Samples which have the lowest $\left[{ }^{230} \mathrm{Th} /{ }^{238} \mathrm{U}\right]_{\text {act }}$ and $\delta^{234} \mathrm{U}$ compositions in conjunction with cogenetic samples that show systematic linear open-system trend away from these can be considered most reliable. This assumption is clearly strengthen if there is multiple samples with have similar low $\left[{ }^{230} \mathrm{Th} /{ }^{238} \mathrm{U}\right]_{\text {act }}-\delta^{234} \mathrm{U}$ compositions.

Several sample fragments from the Henderson Island fossil lagoon display anomalously high $\delta^{234} \mathrm{U}_{i}(>175 \%$ ) (Table 1) and are assumed to yield inaccurate U-series ages. Furthermore, seven corals have U-Th compositions lying outside of the definable limits of the U-series chronometer (Fig. 3). Wall fractions A and B of sample NFL-50 are characterized by the lowest $\delta^{234} \mathrm{U}_{i}$ of $153 \pm$ $6 \%$ and $152 \pm 7 \%$, respectively and are inferred to have experienced the least diagenetic alteration. By coincidence, both values overlap the modern marine value of $147 \%$ and yield respective U-series ages of $585 \pm 13$ and $600 \pm 15 \mathrm{ka}$ (Table 1). The measured bulk sample of the same coral (NFL-50C) shows elevated $\delta^{234} \mathrm{U}$ and $\left[{ }^{230} \mathrm{Th} /{ }^{238} \mathrm{U}\right]_{\text {act }}$ values, and by implication, has experienced significant $\mathrm{U}-\mathrm{Th}$ open-system behaviour, yielding an age of $758 \pm 58 \mathrm{ka}$ and a $\delta^{234} \mathrm{U}_{i}$ of $301 \pm 50 \%$. Although NFL-50A and B are the two apparently least altered samples in the dataset and have $\delta^{234} \mathrm{U}_{i}$ that are identical within error, it is important to note that their measured $\left[{ }^{230} \mathrm{Th} /{ }^{238} \mathrm{U}\right]_{\mathrm{act}}$ and $\delta^{234} \mathrm{U}$ values are statistically distinct (Fig. 3). This suggests that one or both of these sub-samples has experienced subtle U-Th open-system behaviour, potentially leading to anomalous ages that are not detectable on the basis of their back-calculated $\delta^{234} \mathrm{U}_{i}$ alone, and demonstrates that the application of strict $\delta^{234} \mathrm{U}_{i}$ criteria to assess age reliability, should be treated with caution. Given that the difference in the $\left[{ }^{230} \mathrm{Th} /{ }^{238} \mathrm{U}\right]_{\text {act }}$ and $\delta^{234} \mathrm{U}$ compositions between these two wall fractions is relatively minor compared with the much larger offsets observed in their bulk counterpart, a mean conventional age of $593 \pm 23 \mathrm{ka}\left(2 \sigma_{\mathrm{M}}\right)$ based on both sub-samples would provide a robust constraint for the age of the coral. Alternatively, the three NFL-50 sub-samples show a linear diagenetic trend in $\left[{ }^{230} \mathrm{Th} /{ }^{238} \mathrm{U}\right]$ act $-\delta^{234} \mathrm{U}$ space, with sub-sample NFL-50B having the lowest $\left[{ }^{230} \mathrm{Th} /{ }^{238} \mathrm{U}\right]$ act and $\delta^{234} \mathrm{U}$ (Fig. 3). The NFL-50B sub-sample is therefore interpreted to have experienced the least alteration. Indeed $\alpha$-recoil loss, as apposed to gain, of the U-series daughter nuclides is a distinct possibility; however it is unlikely that parts of same well-preserved coral should have experienced Useries daughter loss when other closely-spaced parts have clearly experienced gain (NFL-50C). Furthermore globally distributed reefs show unequivocally evidence of Useries daughter gain, whereas there is no clear evidence for U-series daughter loss. Thus the age $600 \pm 15 \mathrm{ka}$ for NFL-50B is considered to provide the best estimate for the age of this coral, although additional data would be desirable to confirm the closed-system behaviour of this fragment.

\subsection{Model of Thompson et al. (2003)}

When applied to the fossil corals of Henderson Island, the Thompson et al. model yields open-system U-series model ages ranging from $718 \pm 30$ to $572 \pm$ $10 \mathrm{ka}$ (Fig. 4). Several explanations can be considered to explain the large spread in the results. First, it is possible that the range in open-system ages is real and reflects multiple reef-growth events. A second possibility is that all corals formed during a single reef-growth event and the large spread in the open-system ages arises because the associated age uncertainties in the model corrections have been underestimated. A third possibility is that other alteration processes have affected some of the corals that are not accounted for by the model.

Of the five samples for which replicate analyses were obtained, two have open-system ages that are reproducible within their quoted $2 \sigma$ uncertainties (NFL$15[718 \pm 30$ and $688 \pm 27 \mathrm{ka}], \mathrm{NFL}-31$ [660 \pm 13 and $666 \pm 14 \mathrm{ka}]$ ) whereas two others fail to yield reproducible results (NFL-25 [615 \pm 10 and $642 \pm 17 \mathrm{ka}$ ], NFL-27 [614 \pm 12 and $589 \pm 8$ ka] (Fig. 4). The fifth sample (NFL-50) with replicate data points for three sub-samples reveals that the bulk sample NFL-50C, which shows significant U-Th open-system behaviour, has an open-system U-series model age of $572 \pm 10 \mathrm{ka}$. This overlaps with the open-system age of $576 \pm 7 \mathrm{ka}$ determined for the less altered wall fraction NFL-50A, and is in close agreement with, but still statistically distinct from the age of $593 \pm 8 \mathrm{ka}$ obtained for NFL-50B, the second wall fraction of the same sample. 

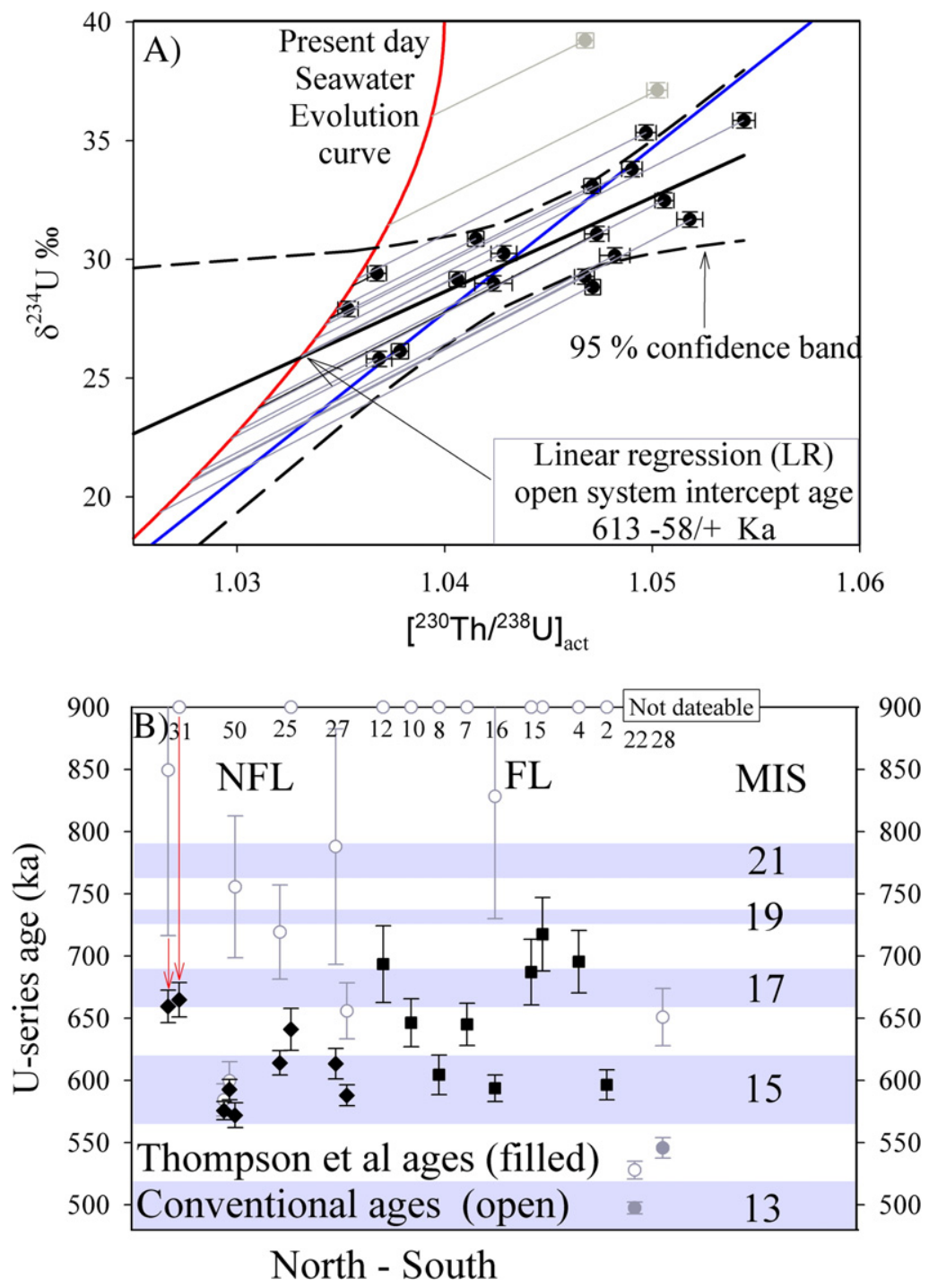

Fig. 4. A. $\left[{ }^{230} \mathrm{Th} /{ }^{238} \mathrm{U}\right]_{\text {act }}$ versus $\delta^{234} \mathrm{U}$ for open-system U-series model ages calculated using the Thompson et al. (2003) model and the linear regression (LR) approach. The intercept of the regression line (black regression line) and the seawater evolution curve gives an model age of $\sim 613 \mathrm{ka}$, but gives rise to a minimum permissible age of $\sim 555 \mathrm{ka}$ and a maximum age that is infinite, taking into consideration the $95 \%$ confidence band (shown by the dashed black lines). The Thompson et al. model calculates open-system U-series ages through a set of $\alpha$-recoil-corrected equations and the seawater evolution curve. The magnitude of the correction for each sample is illustrated by the line drawn from the conventional isotopic composition to the intercept point on the seawater evolution line (grey lines). The two grey points are samples containing $1-2 \%$ calcite (not included in the derivation of the linear regression age). B. Open-system U-series model ages derived using the Thompson et al. model versus geographical relation. Open symbols represent conventionally-dated age estimates (samples lying outside of the conventional dating limit are plotted along the upper axis). Black symbols denote the corresponding open-system U-series model ages for the same samples, and the corrections are exemplified by the downward arrow for NFL31. The Thompson et al. (2003) model is capable of yielding open-system U-series model age estimates for all samples and most samples have open-system ages that lie within an age range of 570-710 ka. Samples FL-22 and NFL-28 contain only 1-2\% calcite but yield open-system ages that are significantly younger than those displayed by the remaining data and are inferred to be inaccurate.

The open-system ages for NFL-50, NFL-27 and four additional fossil lagoon corals (FL-2 [597 $\pm 12 \mathrm{ka}]$, FL-8 [605 $\pm 16 \mathrm{ka}]$, FL-16 [594 $\pm 11 \mathrm{ka}]$ as well as one sub-sample of NFL-25 [615 \pm 10 and $642 \pm 17 \mathrm{ka}]$ ) are all coincident with the timing of MIS 15 (570-620 ka). Six samples (FL-4 [696 $25 \mathrm{ka}]$, FL-12 [694 $\pm 30 \mathrm{ka}]$,
FL-15 [688 \pm 26 and $718 \pm 30 \mathrm{ka}$ ], NFL-31 [660 \pm 13 and

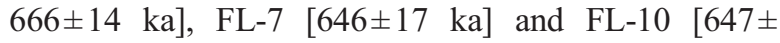
$19 \mathrm{ka}]$ ) yield open-system ages suggesting an older MIS 17 (660-690 ka) origin for some corals.

Most samples show good reproducibility with respect to their open-system ages derived using the Thompson 
et al. model. This is evidenced by the MIS 15 origin of six of the fossil corals including the three sub-samples from the coral NFL-50. This implies that the $\alpha$-recoil addition of ${ }^{230} \mathrm{Th}$ and ${ }^{234} \mathrm{U}$ is a dominant diagenetic process occurring in this fossil reef system and that, in most part, the Thompson et al. model seems to be able to account for it. However, the fact that sub-samples collected from the same coral do not always agree perfectly within the limits of the assigned error bars indicates that additional diagenetic disturbance of the $\mathrm{U}-\mathrm{Th}$ isotopes, other than via the addition of $\alpha$-recoil products, is also occurring in the Henderson Island fossil reefs. These additional mechanisms can potentially modify the U-series systematics and remain undetected during macroscopic screening, as no secondary screening criteria can be used in conjunction with this model. This is not the case for the closed-system U-series approach, which offers the potential to detect diagenetic alteration through variability in the back-calculated $\delta^{234} \mathrm{U}_{i}$. The implication is that caution must be taken when interpreting the reliability of open-system model ages; even if the reproducibility of the model ages improves with respect to the conventional ages, it is important to bear in mind that they can still potentially be inaccurate. It is currently unclear if the suggested older MIS 17 (660-690 ka) origin for some of the corals reflects a true age estimate or is unreliable due to other diagenesis than $\alpha$-recoil redistribution.

Adopting appropriate error bounds for the marine $\delta^{234} \mathrm{U}$ of $147 \pm 20 \%$ for the interval prior to MIS 9 leads for instance to an additional systematic error of $\pm 28 \mathrm{ka}$ in a $600 \mathrm{ka}$ sample when using the Thompson et al. model (Table 1). This additional uncertainty must be incorporated in order to use the open-system ages to the directly date proxy records of past climate change.

\subsection{Model of Villemant and Feuillet}

Applying this model to the Henderson Island corals yields an open-system U-series model age of $889+188 /-$ $139 \mathrm{ka}$ (Table 1). The V\&F model appears limited for the determination of ages for older samples for two reasons. First, it adopts the average conventional U-series age for the entire dataset as a starting point to calculate an opensystem age. However, in older samples, the conventional U-series ages are often biased towards older values (by $100 \mathrm{~s}$ kyr) due to the significant loss in resolution in $\left[{ }^{230} \mathrm{Th} /{ }^{238} \mathrm{U}\right]_{\mathrm{act}}-\delta^{234} \mathrm{U}$ isotopic space. Second, the model calculates an open-system age by correcting the "altered" U-series composition defined by the average conventional age back to the "pristine" composition defined by the intercept with the seawater evolution curve. However, at $>500 \mathrm{ka}$, the orientation of the seawater curve becomes sub-vertical and the intercept becomes difficult to define, which is reflected in the large error limits assigned to the V\&F model age for this dataset. The two abovementioned issues are of minor importance for corals terraces younger than $250 \mathrm{ka}$, as the average conventional age is relatively unbiased and the seawater evolution curve is sub-horizontal in this age range. Consequently, the Thompson et al. and V\&F open-system ages are often similar in this time range (e.g. see (Frank et al., 2006)), however for older samples the basis of the V\&F model may be violated. This shows that the applicability of the V\&F model is significantly weakened for samples approaching secular equilibrium, leading to open-system model ages that are inaccurate.

\subsection{The linear regression open-system model}

For the Henderson Island dataset this model yields an open-system U-series model age of $\sim 613 \mathrm{ka}$. However, when the $95 \%$ confidence uncertainty band for the regression line is taken into account, the upper age limit becomes impossible to distinguish from secular equilibrium, giving rise to an infinite age constraint, whereas the younger intercept gives a lower limit of $555 \mathrm{ka}$ (Fig. 4). These large uncertainties are a function of (a) relatively large scatter in the data about the best-fit regression line, (b) the sensitivity of the linear regression approach to the progressively smaller variations in isotopic composition with elevated age, and (c) the sensitivity of the model to the increasingly parallel orientation of the linear regression line with respect to the seawater evolution curve, both of which are sub-vertical in $\left[{ }^{230} \mathrm{Th} /{ }^{238} \mathrm{U}\right]_{\text {act }}{ }^{-}$ $\delta^{234} \mathrm{U}$ space for older samples, and the intercept of the two curves becomes increasingly difficult to define. The fact that the best-fit line through the full dataset yields an average age of $\sim 613 \mathrm{ka}$ that is in agreement with the conventionally determined result of $600 \pm 15$ ka could be coincidental. Alternatively, it could suggest that the fundamental systematics of this approach are correct, as its potential has been demonstrated for younger reef units (Potter et al., 2004; Scholz and Mangini, 2006, 2007). However, this approach clearly has limited applicability for older samples because of the large age uncertainties involved.

\section{Implications}

A well-preserved fossil coral fragment (NFL-50B) yields an age of $600 \pm 15 \mathrm{ka}$ that overlaps with the timing of the MIS 15 interglaciation (570-620 ka) and has a $\delta^{234} \mathrm{U}_{i}$ of $153 \pm 7 \%$, within the present marine $\delta^{234} \mathrm{U}$ of $147 \%$. 
This age estimate is based on a single U-series data point, whereas 19 other ages were deemed unreliable. However, it can be considered a robust estimate when it is considered in conjunction with the two other sub-samples of this coral and in the context of the systematic U-Th open-system trend shown by all three data points. A similar MIS 15 timing is found for half of the dated corals using the Thompson et al. model (open-system age estimates range from $572 \pm 29$ to $615 \pm 31 \mathrm{ka}$ ), whereas the other half of the fossil corals appear to correlate with MIS 17 (open-system age estimates range from $646 \pm 37$ to $718 \pm 48 \mathrm{ka}$ ).

Insolation predictions for latitude $65^{\circ} \mathrm{N}$ define the MIS 15 interglaciation as three significant maxima, at $577\left(\sim 490 \mathrm{~W} / \mathrm{m}^{2}\right)$, at $598 \mathrm{ka}\left(\sim 475 \mathrm{~W} / \mathrm{m}^{2}\right)$ and at $620 \mathrm{ka}\left(\sim 480 \mathrm{~W} / \mathrm{m}^{2}\right)$ (Fig. 5). Proxy records of past climate spanning MIS 15 are limited to several stacked

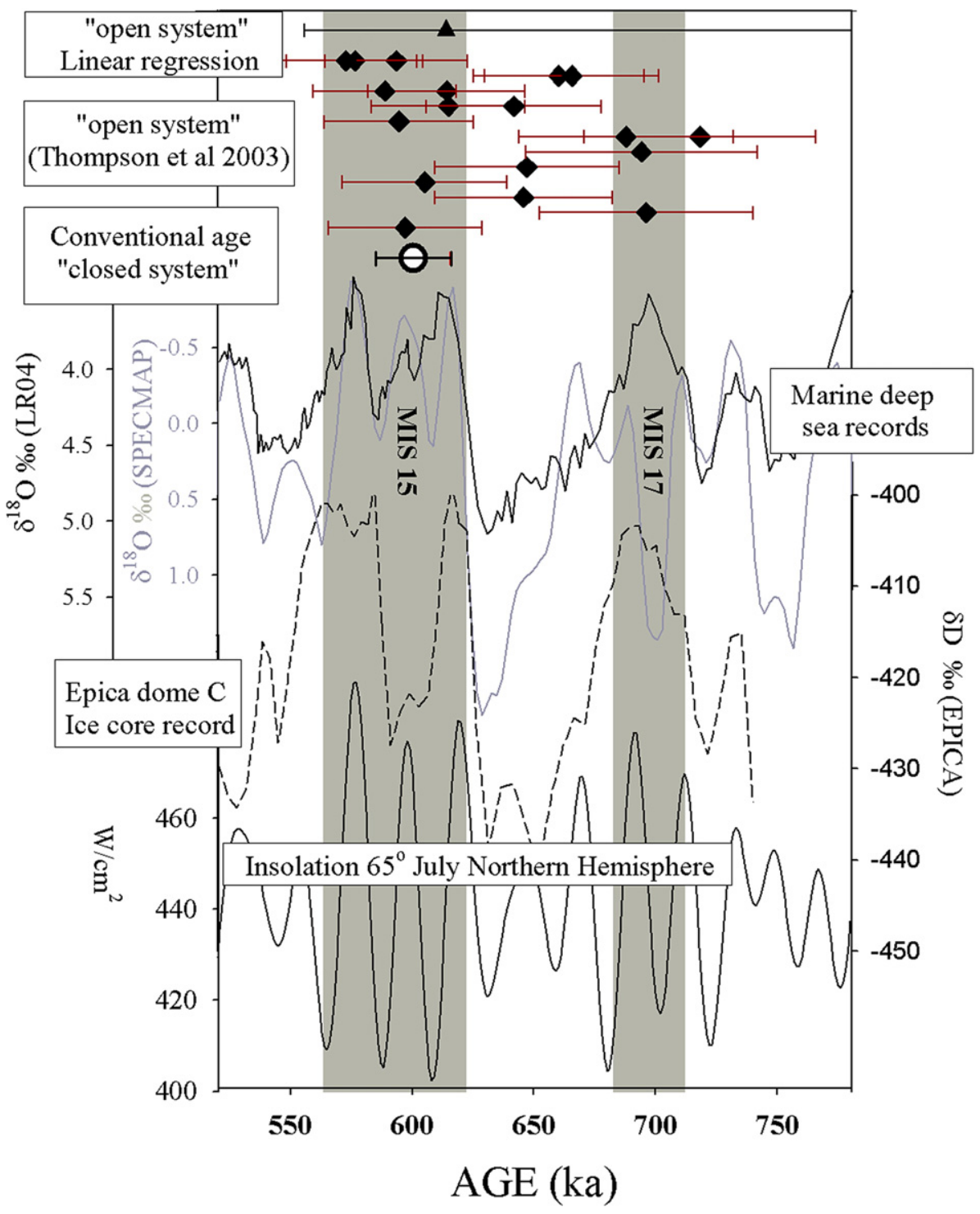

Fig. 5. Comparison of climate records for the interval extending from 780 to $520 \mathrm{ka}$ with the open-system U-series model ages and conventional U-series age estimates for the Henderson Island fossil lagoon corals. The Milankovitch $65^{\circ} \mathrm{N}$ summer insolation curve, the $\delta \mathrm{D}$ signal for the EPICA dome $\mathrm{C}$ Antarctic ice-core (Augustin et al., 2004) and the SPECMAP ((Imbrie et al., 1984); solid grey line) and LR04 ((Lisiecki and Raymo, 2005); solid black line) $\delta^{18} \mathrm{O}$ marine sediment records are shown. Marine Isotope Stage (MIS) interglacials according to the LR04 record are indicated by the grey shaded bands. The conventional U-series age for NFL-50B of $600 \pm 15 \mathrm{ka}$ is in good agreement with the timing of MIS 15 according to the orbitally tuned marine sediment records and the EPICA ice-core record (open black circle). The open-system U-series model ages, using the Thompson et al. (2003) model (black diamonds), with uncertainties including a $\pm 20 \%$ on the seawater evolution curve, display considerable scatter, however with ages corresponding to the MIS 15 or MIS 17 periods. Larger error limits are associated with the age estimates for the linear regression model (black triangle). 
$\delta^{18} \mathrm{O}$ deep-sea sediment records of global ice volumemarine temperature (Imbrie et al., 1984; Bassinot et al., 1994; Lisiecki and Raymo, 2005) and the recently retrieved ice-core from Dome C, Antarctica which yields a $\delta \mathrm{D}$ record (a proxy for Antarctic air temperature) extending back to $\sim 800 \mathrm{ka}$ (Augustin et al., 2004; Jouzel et al., 2007). The ice-core record displays two warm intervals during MIS 15 at $\sim 630-610 \mathrm{ka}$ and $\sim 580-565$ ka during which Antarctic air temperatures were $1-2^{\circ}$ lower than today. The period at $595-585 \mathrm{ka}$, correlated with MIS 15.3, is represented by cooler temperatures ( $4-5^{\circ}$ colder than today). A similar pattern is seen in the stacked $\delta^{18} \mathrm{O}$ deep-sea sediment records of Lisiecki and Raymo (2005), which showed intense $\delta^{18} \mathrm{O}$ signals for MIS 15.1 (581-567 ka) and MIS 15.5 (621$608 \mathrm{ka})$, both of which are more pronounced compared with MIS 15.3 (598-589 ka). The estimated timing for coral growth of $600 \pm 15 \mathrm{ka}$ at Henderson Island does not have sufficient resolution to distinguish between different sub-stages of MIS 15 , as the timing overlaps both MIS 15.3 and MIS 15.5. However, by correlation with the above-mentioned climate records, we infer that the timing of reef formation at Henderson Island most likely correlates with MIS 15.5, representing the warmest climate episode, as opposed to the less intense warm peak representing MIS 15.3 in both the ice-core and $\delta^{18} \mathrm{O}$ deep-sea sediment records (Fig. 5).

All the above-mentioned paleoclimate records have been assigned an orbitally tuned chronology and are, by definition, in agreement with the Milankovitch theory. However, a very recent study by Florindo et al. (2007), based on the Ar-Ar dating of buried sedimentary aggradational deposits, suggests that MIS 15 could have initiated as early as $649 \pm 4$ ka thereby predating Milankovitch's predictions by tens of thousands of years. This early initiation of MIS 15 is not supported by our study, on the basis of the conventional U-series age estimate of $600 \pm 15 \mathrm{ka}$.

Sea-level chronologies aside, the uplift history of Henderson Island are complex. By comparing the presentday elevation of the Henderson Island fossil lagoon to the modelled sea-level variation of Bintanja et al. (2005) it is possible to determine the net uplift of the island since $\sim 600 \mathrm{ka}$. The model predicts two sea-level high-stands during MIS 15 of $-15 \pm 10 \mathrm{~m}$ at $\sim 580 \mathrm{ka}$ and $-25 \pm 10 \mathrm{~m}$ at $\sim 615$ ka relative to present sea-level. The Henderson Island fossil lagoon is located $25 \pm 5 \mathrm{~m}$ above sea-level at present, and assuming reef growth at $\sim 615 \mathrm{ka}$ formed in water depths of $0-5 \mathrm{~m}$, the implication is that the island must have experienced a net uplift of $\sim 55 \pm 12 \mathrm{~m}$ since that time.

The timing of the earliest coral atoll development on Henderson Island extends back to at least MIS 15
(570-620 ka) and is important with respect to the initiation of global Quaternary tropical coral reef development which is not well-constrained. The development of the Great Barrier Reef complex at the Australian northeast coast is thought to have commenced at $600 \pm 280 \mathrm{ka}$ based on correlation with the strontium isotope curve and paleo-magnetic data (Alexander et al., 2001). This overlaps with the timing of the Ryukyu Group reef formation in Japan, suggesting that this may be a synchronous event across the entire tropical Pacific (Sakai, 2003). The reason for this increase in shallow water coral formation is still debated, either owing to increased warming of the Pacific warm pool (Sakai, 2003) or through changes in ocean chemistry (Lawrence and Herbert, 2005), but the observations for both Australia and Japan are in agreement with the timing of coral atoll development on Henderson Island, which also began as early as MIS 15. The initiation of coral reef growth on Henderson Island may have been dependent upon the supply and recruitment of coral larvae sourced from $\mathrm{Pa}-$ cific islands further to the north-west and could indicate that MIS 15 coral reef development was synchronous across much of the Indo-Pacific region.

\section{Conclusions}

- A conventional U-series age for a well-preserved fossil coral from the Henderson Island fossil lagoon yields an age of $600 \pm 15 \mathrm{ka}$, and provides an absolute age constraint for the timing of reef development during the MIS 15 interglaciation.

- A significant number of U-Th open-system model ages derived using the Thompson et al. model also coincide with the timing of MIS 15 (572 \pm 29 to $615 \pm$ $31 \mathrm{ka})$. This model also suggests a MIS 17 (646 \pm 37 to $718 \pm 48 \mathrm{ka}$ ) origin for the remaining fossil corals. The data suggest that the $\alpha$-recoil addition of ${ }^{230} \mathrm{Th}$ and ${ }^{234} \mathrm{U}$ is a dominant diagenetic process occurring in fossil reef systems, and the Thompson et al. model appears capable of reasonably correcting for most diagenetic shifts in the U-series isotopic composition. However, the observational data also provide evidence that alteration effects acting in addition to $\alpha$ recoil processes are modifying the U-series systematics in at least some of the Henderson Island samples, as has been observed at other fossil reef localities.

- Application of the Villemant and Feuillet model to older coral samples approaching secular equilibrium does not produce reliable results, primarily due to the change in the $\delta^{234} \mathrm{U}$ seawater evolution curve from sub-horizontal to an increasingly vertical orientation in U-series isotope space for ages $>500 \mathrm{ka}$. 
- The linear regression open-system model approach may be able to obtain robust age estimates but is not useful for older samples due to large age uncertainties.

\section{Acknowledgments}

We are grateful to the valuable support of Felix Oberli, Helen Williams and Sarah Woodland, as well as Urs Menet, Heiri Baur and Bruno Rütsche, and the rest of the IGMR group who expend time and effort to ensure the smooth running of the MC-ICPMS facilities at IGMR. Damian Kelleher, Alve Henricson and the crew of the Research Vessel 'Searcher' are gratefully thanked for their efforts in making the Henderson Island expedition a success. Thanks goes to Judith Mackenzie, David Richards for discussions, Peggy Delaney for the editorial handling, and four anonymous reviewers which provided very careful reviews that greatly improved the final manuscript.

\section{Appendix A. Supplementary data}

Supplementary data associated with this article can be found, in the online version, at doi:10.1016/j.epsl.2007. 10.010 .

\section{References}

Alexander, I., Andres, M.S., Braithwaite, C.J.R., Braga, J.C., Cooper, M.J., Davies, P.J., Elderfield, P.J., Gilmour, H., Kay, M.A., Kroon, R.L.F., McKenzie, D., Montaggioni, J.A., Skinner, L.F., Thompson, A., Vasconcelos, R., Webster, C.J., Wilson, P.A., 2001. New constraints on the origin of the Australian Great Barrier Reef: results from an international project of deep coring. Geology 29 (6), 483-486.

Andersen M.B., 2006. The Precise Measurement of Uranium-Series Isotopes in the Marine Enviroment. Ph.D thesis, ETH Zürich, $1-224$.

Andersen, M.B., Stirling, C.H., Potter, E.K., Halliday, A.N., 2004. Toward epsilon levels of measurement precision on ${ }^{234} \mathrm{U} /{ }^{238} \mathrm{U}$ by using MC-ICPMS. Int. J. Mass Spectrom. 237 (2-3), 107-118.

Andersen, M.B., Stirling, C.H., Porcelli, D., Halliday, A.H., Andersson, P.S., Baskaran, M., 2007. The tracing of riverine U in Arctic seawater with very precise ${ }^{234} \mathrm{U} /{ }^{238} \mathrm{U}$ measurements. Earth Planet. Sci. Lett. 259, 171-185.

Augustin, L., Barbante, C., Barnes, P.R.F., Barnola, J.M., Bigler, M., Castellano, E., Cattani, O., Chappellaz, J., DahlJensen, D., Delmonte, B., Dreyfus, G., Durand, G., Falourd, S., Fischer, H., Fluckiger, J., Hansson, M.E., Huybrechts, P., Jugie, R., Johnsen, S.J., Jouzel, J., Kaufmann, P., Kipfstuhl, J., Lambert, F., Lipenkov, V.Y., Littot, G.V.C., Longinelli, A., Lorrain, R., Maggi, V., MassonDelmotte, V., Miller, H., Mulvaney, R., Oerlemans, J., Oerter, H., Orombelli, G., Parrenin, F., Peel, D.A., Petit, J.R., Raynaud, D., Ritz, C., Ruth, U., Schwander, J., Siegenthaler, U., Souchez, R., Stauffer, B., Steffensen, J.P., Stenni, B., Stocker, T.F., Tabacco, I.E., Udisti, R., van de Wal, R.S.W., van den Broeke, M., Weiss, J., Wilhelms, F.,
Winther, J.G., Wolff, E.W., Zucchelli, M., 2004. Eight glacial cycles from an Antarctic ice core. Nature 429 (6992), 623-628.

Ayling, B.F., McCulloch, M.T., Gagan, M.K., Stirling, C.H., Andersen, M.B., Blake, S.G., 2006. $\mathrm{Sr} / \mathrm{Ca}$ and $\delta^{18} \mathrm{O}$ seasonality in a porites coral from the MIS 9 (339-303 ka) interglacial. Earth Planet. Sci. Lett. 248 (1-2), 462-475.

Bard, E., Hamelin, B., Fairbanks, R.G., 1990. U-Th ages obtained by mass-spectrometry in corals from Barbados - sea-level during the past 130,000 years. Nature 346 (6283), 456-458.

Bard, E., Fairbanks, R.G., Hamelin, B., Zindler, A., Hoang, C.T., 1991. U-234 anomalies in corals older than 150,000 years. Geochim. Cosmochim. Acta 55 (8), 2385-2390.

Bard, E., Jouannic, C., Hamelin, B., Pirazzoli, P., Arnold, M., Faure, G., Sumosusastro, P., Syaefudin, 1996. Pleistocene sea levels and tectonic uplift based on dating of corals from Sumba Island, Indonesia. Geophys. Res. Lett. 23 (12), 1473-1476.

Bard, E., Antonioli, F., Silenzi, S., 2002. Sea-level during the penultimate interglacial period based on a submerged stalagmite from Argentarola cave (Italy). Earth Planet. Sci. Lett. 196 (3-4), 135-146.

Bassinot, F.C., Labeyrie, L.D., Vincent, E., Quidelleur, X., Shackleton, N.J., Lancelot, Y., 1994. The astronomical theory of climate and the age of the Brunhes-Matuyama magnetic reversal. Earth Planet. Sci. Lett. 126 (1-3), 91-108.

Bender, M.L., Fairbanks, R.G., Taylor, F.W., Matthews, R.K., Goddard, J.G., Broecker, W.S., 1979. Uranium-series dating of the Pleistocene reef tracts of Barbados, West-Indies. Geol. Soc. Amer. Bull. 90 (6), 577-594.

Benton, T.G., Spencer, T., 1995. The birds of Henderson Island ecological-studies in a near pristine ecosystem. Biol. J. Linn. Soc. $56(1-2), 147-148$.

Bintanja, R., van de Wal, R.S.W., Oerlemans, J., 2005. Modelled atmospheric temperatures and global sea levels over the past million years. Nature 437 (7055), 125-128.

Blake, S.G., 1995. Late Quaternary history of Henderson Island, Pitcairn Group. Biol. J. Linn. Soc. 56 (1-2), 43-62.

Broecker, W.S., 2003. Does the trigger for abrupt climate change reside in the ocean or in the atmosphere? Science 300 (5625), $1519-1522$.

Camoin, G.F., Ebren, P., Eisenhauer, A., Bard, E., Faure, G., 2001. A 300,000-yr coral reef record of sea level changes, Mururoa atoll (Tuamotu archipelago, French Polynesia). Palaeogeogr. Palaeoclimatol. Palaeoecol. 175 (1-4), 325-341.

Chabaux, F., Riotte, J., Dequincey, O., 2003. U-Th-Ra fractionation during weathering and river transport. Uranium-Series Geochemistry, vol. 52, pp. 533-576.

Chen, J.H., Edwards, R.L., Wasserburg, G.J., 1986. ${ }^{238} \mathrm{U},{ }^{234} \mathrm{U}$ and ${ }^{232} \mathrm{Th}$ in seawater. Earth Planet. Sci. Lett. 80 (3-4), 241-251.

Cheng, H., Edwards, R.L., Hoff, J., Gallup, C.D., Richards, D.A., Asmerom, Y., 2000. The half-lives of uranium-234 and thorium230. Chem. Geol. 169 (1-2), 17-33.

Cutler, K.B., Gray, S.C., Burr, G.S., Edwards, R.L., Taylor, F.W., Cabioch, G., Beck, J.W., Cheng, H., Moore, J., 2004. Radiocarbon calibration and comparison to $50 \mathrm{kyr}$ BP with paired ${ }^{14} \mathrm{C}$ and ${ }^{230} \mathrm{Th}$ dating of corals from Vanuatu and Papua New Guinea. Radiocarbon 46 (3), 1127-1160.

Delanghe, D., Bard, E., Hamelin, B., 2002. New TIMS constraints on the uranium-238 and uranium-234 in seawaters from the main ocean basins and the Mediterranean Sea. Mar. Chem. 80 (1), 79-93.

Duncan, R.A., McDougal, I., Carter, R.M., Coombs, D.S., 1974. Pitcairn Island - another Pacific hot spot. Nature 251 (5477), 679-682. 
Edwards, R.L., Chen, J.H., Ku, T.L., Wasserburg, G.J., 1987. Precise timing of the last interglacial period from mass-spectrometric determination of ${ }^{230} \mathrm{Th}$ in corals. Science 236 (4808), 1547-1553.

Edwards, R.L., Beck, J.W., Burr, G.S., Donahue, D.J., Chappell, J.M.A., Bloom, A.L., Druffel, E.R.M., Taylor, F.W., 1993. A large drop in atmospheric ${ }^{14} \mathrm{C} /{ }^{12} \mathrm{C}$ and reduced melting in the younger dryas, documented with ${ }^{230} \mathrm{Th}$ ages of corals. Science 260 (5110), 962-968.

Edwards, R.L., Gallup, C.D., Cheng, H., 2003. Uranium-series dating of marine and lacustrine carbonates. Uranium-Series Geochemistry, vol. 52 , pp. $363-405$.

Esat, T.M., 1995. Charge collection thermal ion mass-spectrometry of thorium. Int. J. Mass Spectrom. Ion Process. 148 (3), 159-170.

Esat, T.M., Yokoyama, Y., 2006. Variability in the uranium isotope composition of the oceans over glacial-interglacial timescales. Geochim. Cosmochim. Acta 70, 4140-4150.

Esat, T.M., McCulloch, M.T., Chappell, J., Pillans, B., Omura, A., 1999. Rapid fluctuations in sea level recorded at Huon Peninsula during the penultimate deglaciation. Science 283 (5399), 197-201.

Fietzke, J., Liebetrau, V., Eisenhauer, A., Dullo, C., 2005. Determination of uranium isotope ratios by multi-static MIC-ICP-MS: method and implementation for precise U- and Th-series isotope measurements. J. Anal. At. Spectrom. 20 (5), 395-401.

Florindo, F., Karner, D.B., Marra, F., Renne, P.R., Roberts, A.P., Weaver, R., 2007. Radioisotopic age constraints for glacial terminations IX and VII from aggradational sections of the Tiber River delta in Rome, Italy. Earth Planet. Sci. Lett. 256 (1-2), 61-80.

Frank, N., Turpin, L., Cabioch, G., Blamart, D., Tressens-Fedou, M., Colin, C., Jean-Baptiste, P., 2006. Open system U-series ages of corals from a subsiding reef in New Caledonia: implications for sea level changes, and subsidence rate. Earth Planet. Sci. Lett. 249 (3-4), 274-289.

Gallup, C.D., Edwards, R.L., Johnson, R.G., 1994. The timing of high sea levels over the past 200,000 years. Science 263 (5148), 796-800.

Goldstein, S.J., Stirling, C.H., 2003. Techniques for measuring uranium-series nuclides: 1992-2002. Uranium-Series Geochemistry, vol. 52, pp. 23-57.

Hamelin, B., Bard, E., Zindler, A., Fairbanks, R.G., 1991. ${ }^{234} \mathrm{U} /{ }^{238} \mathrm{U}$ mass-spectrometry of corals - how accurate is the U-Th age of the last interglacial period. Earth Planet. Sci. Lett. 106 (1-4), $169-180$

Henderson, G.M., 2002. Seawater $\left({ }^{234} U{ }^{238} U\right)$ during the last 800 thousand years. Earth Planet. Sci. Lett. 199 (1-2), 97-110.

Henderson, G.M., Slowey, N.C., 2000. Evidence from U-Th dating against Northern Hemisphere forcing of the penultimate deglaciation. Nature 404 (6773), 61-66.

Henderson, G.M., Slowey, N.C., Fleisher, M.Q., 2001. U-Th dating of carbonate platform and slope sediments. Geochim. Cosmochim. Acta 65 (16), 2757-2770.

Hoffmann, D.L., Richards, D.A., Elliott, T.R., Smart, P.L., Coath, C.D., Hawkesworth, C.J., 2005. Characterisation of secondary electron multiplier nonlinearity using MC-ICPMS. Int. J. Mass Spectrom. 244 (2-3), 97-108.

Imbrie, J., Hays, J.D., Martinson, D.G., McIntyre, A., Morley, J.J., Pisias, N.G., Prell, W., Shackleton, N.J., 1984. The orbital theory of Pleistocene climate: support from a revised chronology of the marine $\delta^{18} \mathrm{O}$ record. In: Berger, A. (Ed.), Milankovitch and Climate, Part 1. D. Reidel Publishing Company, pp. 269-303.

Irving, R.A., 1995. Near-shore bathymetry and reef biotopes of Henderson Island, Pitcairn Group. Biol. J. Linn. Soc. 56 (1-2), 309-324.
Jouzel, J., Masson-Delmotte, V., Cattani, O., Dreyfus, G., Falourd, S., Hoffmann, G., Minster, B., Nouet, J., Barnola, J.M., Chappellaz, J., Fischer, H., Gallet, J.C., Johnsen, S., Leuenberger, M., Loulergue, L., Luethi, D., Oerter, H., Parrenin, F., Raisbeck, G., Raynaud, D., Schilt, A., Schwander, J., Selmo, E., Souchez, R., Spahni, R., Stauffer, B., Steffensen, J.P., Stenni, B., Stocker, T.F., Tison, J.L., Werner, M., Wolff, E.W., 2007. Orbital and millennial Antarctic climate variability over the past 800,000 years. Science 317 (5839), 793-796.

Lawrence, K.T., Herbert, T.D., 2005. Late quaternary sea-surface temperatures in the western coral sea: implications for the growth of the Australian Great Barrier Reef. Geology 33 (8), 677-680.

Lisiecki, L.E., Raymo, M.E., 2005. A Pliocene-Pleistocene stack of 57 globally distributed benthic $\delta^{18} \mathrm{O}$ records. Paleoceanography 20 (2) (art no PA1003).

Ludwig, K.R., Simmons, K.R., Szabo, B.J., Winograd, I.J., Landwehr, J.M., Riggs, A.C., Hoffman, R.J., 1992. Mass-spectrometric ${ }^{230} \mathrm{Th}-{ }^{234} \mathrm{U}-{ }^{238} \mathrm{U}$ dating of the Devils-Hole calcite vein. Science 258 (5080), 284-287.

Luo, X.Z., Rehkämper, M., Lee, D.C., Halliday, A.N., 1997. High precision ${ }^{230} \mathrm{Th} /{ }^{232} \mathrm{Th}$ and ${ }^{234} \mathrm{U} /{ }^{238} \mathrm{U}$ measurements using energyfiltered ICP magnetic sector multiple collector mass spectrometry. Int. J. Mass Spectrom. 171 (1-3), 105-117.

McCulloch, M.T., Esat, T., 2000. The coral record of last interglacial sea levels and sea surface temperatures. Chem. Geol. 169 (1-2), 107-129.

McNutt, M., 1978. Lithospheric flexure and uplifted atolls. J. Geophys. Res. 83 (NB3), 1206-1212.

Milankovitch M.M., (1941) Canon of Insolation and the Ice-age Problem (Königlich Serbische Akademie, Belgrade, Yugoslavia, 1941). J. Imbrie, K.P. Imbrie, Ice Ages: Solving the Mystery (Enslow, Short Hills, NJ, 1979).

Pandolfi, J.M., 1995. Geomorphology of the uplifted Pleistocene atoll at Henderson Island, Pitcairn Group. Biol. J. Linn. Soc. 56 (1-2), 63-77.

Paulay, G., 1989. Marine invertebrates of the Pitcairn Islands: species composition and biogeography of corals, molluscs, and echinoderms. Atoll Res. Bull. 326, 1-28.

Petit, J.R., Jouzel, J., Raynaud, D., Barkov, N.I., Barnola, J.M., Basile, I., Bender, M., Chappellaz, J., Davis, M., Delaygue, G., Delmotte, M., Kotlyakov, V.M., Legrand, M., Lipenkov, V.Y., Lorius, C., Pepin, L., Ritz, C., Saltzman, E., Stievenard, M., 1999. Climate and atmospheric history of the past 420,000 years from the Vostok ice core, Antarctica. Nature 399 (6735), 429-436.

Potter, E.K., Esat, T.A., Schellmann, G., Radtke, U., Lambeck, K., McCulloch, M.T., 2004. Suborbital-period sea-level oscillations during marine isotope substages $5 \mathrm{a}$ and $5 \mathrm{c}$. Earth Planet. Sci. Lett. 225 (1-2), 191-204.

Potter, E.K., Stirling, C.H., Andersen, M.B., Halliday, A.N., 2005. High precision Faraday collector MC-ICPMS thorium isotope ratio determination. Int. J. Mass Spectrom. 247 (1-3), 10-17.

Richards, D.A., Smart, P.L., Edwards, R.L., 1994. Maximum sea levels for the last glacial period from U-series ages of submerged speleothems. Nature 367 (6461), 357-360.

Richter, F.M., Turekian, K.K., 1993. Simple-models for the geochemical response of the ocean to climatic and tectonic forcing. Earth Planet. Sci. Lett. 119 (1-2), 121-131.

Robinson, L.F., Henderson, G.M., Slowey, N.C., 2002. U-Th dating of marine isotope stage 7 in Bahamas slope sediments. Earth Planet. Sci. Lett. 196 (3-4), 175-187.

Robinson, L.F., Belshaw, N.S., Henderson, G.M., 2004a. U and Th concentrations and isotope ratios in modern carbonates and waters from the Bahamas. Geochim. Cosmochim. Acta 68 (8), 1777-1789. 
Robinson, L.F., Henderson, G.M., Hall, L., Matthews, I., 2004 b. Climatic control of riverine and seawater uranium-isotope ratios. Science 305 (5685), 851-854.

Robinson, L.F., Adkins, J.F., Fernandez, D.P., Burnett, D.S., Wang, S.L., Gagnon, A.C., Krakauer, N., 2006. Primary U distribution in scleractinian corals and its implications for $U$ series dating. Geochem. Geophys. Geosys. 7.

Sakai, S., 2003. Shallow-water carbonates record marginal to open ocean Quaternary paleoceanographic evolution. Paleoceanography 18 (4).

Scholz, D., Mangini, A., 2006. Estimating the uncertainty of coral isochron U-Th ages. Quat. Geochronol. 1 (4), 279-288.

Scholz, D., Mangini, A., 2007. How precise are U-series coral ages? Geochim. Cosmochim. Acta 71 (8), 1935-1948.

Scholz, D., Mangini, A., Felis, T., 2004. U-series dating of diagenetically altered fossil reef corals. Earth Planet. Sci. Lett. 218 (1-2), 163-178.

Spencer, T., 1995. The Pitcairn Islands, South-Pacific Ocean — plate tectonic and climatic contexts. Biol. J. Linn. Soc. 56 (1-2), 13-42.

Stein, M., Wasserburg, G.J., Aharon, P., Chen, J.H., Zhu, Z.R., Bloom, A., Chappell, J., 1993. TIMS U-series dating and stable isotopes of the last interglacial event in Papua-New-Guinea. Geochim. Cosmochim. Acta 57 (11), 2541-2554.

Stirling, C.H., Esat, T.M., McCulloch, M.T., Lambeck, K., 1995. High-precision U-series dating of corals from Western-Australia and implications for the timing and duration of the last interglacial. Earth Planet. Sci. Lett. 135 (1-4), 115-130.

Stirling, C.H., Esat, T.M., Lambeck, K., McCulloch, M.T., 1998. Timing and duration of the last interglacial: evidence for a restricted interval of widespread coral reef growth. Earth Planet. Sci. Lett. 160 (3-4), 745-762.

Stirling, C.H., Esat, T.M., Lambeck, K., McCulloch, M.T., Blake, S.G., Lee, D.C., Halliday, A.N., 2001. Orbital forcing of the marine isotope stage 9 interglacial. Science 291 (5502), 290-293.

Stirling, C.H., Andersen, M.B., Potter, E.-K., Halliday, A.N., in press. Low temperature Isotope Fractionation of uranium. Earth Planetary Scientific Letters.

Thompson, W.G., Goldstein, S.L., 2005. Open-system coral ages reveal persistent suborbital sea-level cycles. Science 308 (5720), 401-404.

Thompson, W.G., Goldstein, S.L., 2006. A radiometric calibration of the SPECMAP timescale. Quat. Sci. Rev. 25 (23-24), 3207-3215.

Thompson, W.G., Spiegelman, M.W., Goldstein, S.L., Speed, R.C., 2003. An open-system model for U-series age determinations of fossil corals. Earth Planet. Sci. Lett. 210 (1-2), 365-381.

Villemant, B., Feuillet, N., 2003. Dating open systems by the ${ }^{238} \mathrm{U}^{2}{ }^{234} \mathrm{U}-{ }^{230} \mathrm{Th}$ method: application to Quaternary reef terraces. Earth Planet. Sci. Lett. 210 (1-2), 105-118.

Yokoyama, Y., Esat, T.M., Lambeck, K., 2001. Coupled climate and sea-level changes deduced from Huon Peninsula coral terraces of the last ice age. Earth Planet. Sci. Lett. 193 (3-4), 579-587. 